Research article

Open Access

\title{
Heat shock protein-90-alpha, a prolactin-STAT5 target gene identified in breast cancer cells, is involved in apoptosis regulation
}

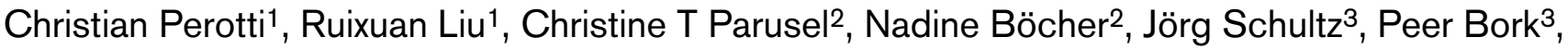 \\ Edith Pfitzner ${ }^{2}$, Bernd Groner ${ }^{2}$ and Carrie S Shemanko ${ }^{1,2}$
}

\author{
1Department of Biological Sciences, University of Calgary, 2500 University Drive NW, Calgary, AB, T2N 1N4, Canada \\ ${ }^{2}$ Georg-Speyer-Haus, Institute for Biomedical Research, Paul Ehrlich Strasse, 42-44, D-60596, Frankfurt am Main, Germany \\ ${ }^{3}$ European Molecular Biology Laboratories, Meyerhofstrasse 1, 69012 Heidelberg, Germany \\ Corresponding author: Carrie S Shemanko, shemanko@ucalgary.ca
}

Received: 4 Jul 2008 Revisions requested: 19 Aug 2008 Revisions received: 21 Sep 2008 Accepted: 13 Nov 2008 Published: 13 Nov 2008

Breast Cancer Research 2008, 10:R94 (doi:10.1186/bcr2193)

This article is online at: http://breast-cancer-research.com/content/10/6/R94

(c) 2008 Borley et al.; licensee BioMed Central Ltd.

This is an open access article distributed under the terms of the Creative Commons Attribution License (http://creativecommons.org/licenses/by/2.0), which permits unrestricted use, distribution, and reproduction in any medium, provided the original work is properly cited.

\begin{abstract}
Introduction The prolactin-Janus-kinase-2-signal transducer and activator of transcription-5 (JAK2-STAT5) pathway is essential for the development and functional differentiation of the mammary gland. The pathway also has important roles in mammary tumourigenesis. Prolactin regulated target genes are not yet well defined in tumour cells, and we undertook, to the best of our knowledge, the first large genetic screen of breast cancer cells treated with or without exogenous prolactin. We hypothesise that the identification of these genes should yield insights into the mechanisms by which prolactin participates in cancer formation or progression, and possibly how it regulates normal mammary gland development.
\end{abstract}

Methods We used subtractive hybridisation to identify a number of prolactin-regulated genes in the human mammary carcinoma cell line SKBR3. Northern blotting analysis and luciferase assays identified the gene encoding heat shock protein 90 -alpha (HSP9OA) as a prolactin-JAK2-STAT5 target gene, whose function was characterised using apoptosis assays.

Results We identified a number of new prolactin-regulated genes in breast cancer cells. Focusing on HSP9OA, we determined that prolactin increased HSP9OA mRNA in cancerous human breast SKBR3 cells and that STAT5B preferentially activated the HSP9OA promoter in reporter gene assays. Both prolactin and its downstream protein effector, HSP90 $\alpha$, promote survival, as shown by apoptosis assays and by the addition of the HSP90 inhibitor, 17-allylamino-17demethoxygeldanamycin (17-AAG), in both untransformed HC11 mammary epithelial cells and SKBR3 breast cancer cells. The constitutive expression of $H S P 90 A$, however, sensitised differentiated HC11 cells to starvation-induced wild-type p53independent apoptosis. Interestingly, in SKBR3 breast cancer cells, HSP90 $\alpha$ promoted survival in the presence of serum but appeared to have little effect during starvation.

Conclusions In addition to identifying new prolactin-regulated genes in breast cancer cells, we found that prolactin-JAK2STAT5 induces expression of the HSP9OA gene, which encodes the master chaperone of cancer. This identifies one mechanism by which prolactin contributes to breast cancer. Increased expression of HSP9OA in breast cancer is correlated with increased cell survival and poor prognosis and HSP9O $\alpha$ inhibitors are being tested in clinical trials as a breast cancer treatment. Our results also indicate that HSP90 $\alpha$ promotes survival depending on the cellular conditions and state of cellular transformation.

\section{Introduction}

The proliferation and functional differentiation of mammary epithelial cells is highly dependent on the action of prolactin [1].
These effects of prolactin are mainly mediated through the prolactin receptor Janus kinase-2-signal transducers and activators of transcription-5 (JAK2-STAT5) pathway, and results in

17-AAG: 17-allylamino-17-demethoxygeldanamycin; bp: base pairs; C/S: cytokine inducible SH2 containing protein; EGF: epidermal growth factor; ERBB2: erythroblastic leukaemia viral oncogene homolog 2; HRP: horseradish peroxidase; HSP90: heat shock protein 90; JAK2: Janus kinase-2; STAT: signal transducers and activators of transcription. 
mammary epithelial cell proliferation and the differentiation of alveolar cells during pregnancy. On weaning, a large proportion of these alveolar cells die off in a massive wave of apoptosis and tissue remodelling [2]. Generally speaking, prolactin and STAT5 are thought to induce genes for survival in the differentiated cells, while STAT3 is thought to induce genes required for apoptosis [3].

Prolactin signalling has also been implicated in mammary and breast cancer, including invasive [4] and non-invasive breast cancer [5-7]. The transgenic expression of prolactin results in increased tumour formation in mice [8-10]. Crossing prolactindeficient mice with oncogenic polyoma middle-T antigen transgenic mice demonstrated that prolactin decreased the latency of tumour formation and increased tumour growth [11]. Using a cross with SV-40T oncogene transgenics and prolactin receptor null mice, and transplant of the epithelium to endocrine normal mice, the prolactin receptor was demonstrated to increase neoplasia and positively impact the transition to invasive carcinoma [12].

In humans, high serum prolactin levels increase the risk of breast cancer for women $[4,7,13]$. Although expression of the prolactin receptor is more often found in oestrogen receptorpositive breast tumours, which tend to have a better prognosis, it is also found in many oestrogen receptor-negative breast tumours [14]. The gene encoding the prolactin receptor is also highly expressed in a subset of breast tumours with poor prognosis and is part of a set of prognostic gene markers [15]. Prolactin is not only secreted by the pituitary gland, but is also produced locally in the majority of breast tumours and is thought to act in an autocrine and/or paracrine fashion [6]. Although prolactin can transduce signals through multiple pathways, the activation of STAT family members, which are downstream of prolactin and other growth factors has also been implicated in tumourigenesis $[16,17]$. Prolactin-regulated target genes are not yet well defined in breast cancer cells. Only recently have large-scale attempts at identifying prolactin target genes been performed using the mammary gland and these have been limited to normal mammary epithelial cells [18-24].

The heat shock protein 90-alpha (HSP90 $\alpha$ ) protein is referred to as the cancer chaperone [25,26], a molecular chaperone of proteins involved in essential signal transduction pathways regulating proliferation, differentiation, apoptosis, angiogenesis, metastasis, oncogenesis [27-29], genetic variation [30,31], invasion [32] and cellular transformation [33]. It is distinct from HSP9O $\beta$ [34], a protein encoded by a related gene, which is constitutively expressed. HSP90 $\alpha$ gene expression is elevated in breast cancers [35-37] and is correlated with decreased patient survival [35-37]. HSP90 inhibitors bind specifically and preferentially to HSP9O $\alpha$ and $\beta$ in cancerous cells versus normal cells [38]. Inhibition of HSP9O results in the proteosomal degradation of many HSP90 client proteins.
Client proteins include erythroblastic leukaemia viral oncogene homolog 2 (ERBB2) and AKT/protein kinase B [39] and their loss results in apoptosis. HSP90 inhibitors, such as geldanamycin derivatives like 17-allylamino-17-demethoxygeldanamycin (17-AAG), have entered clinical trials for the treatment of breast and prostate cancer and melanoma $[27,40,41]$.

Prolactin-regulated target genes in breast cancer cells are likely to also function in normal cells, but under appropriate regulation. We hypothesised that prolactin-regulated genes in breast cancer cells would also have important functions in non-transformed mammary epithelial cells and may potentially contribute to cancer progression when deregulated. Using a subtractive hybridisation approach, we identified a number of cancer-related genes whose expression is modified by the addition of prolactin in the human breast adenocarcinoma cell line, SKBR3. We specifically identified the therapeutically important gene, HSP9OA as a STAT5 regulated target gene. HSP9OA appears to regulate survival differentially depending on the cellular levels of its protein product $\mathrm{HSP} 90 \alpha$, the presence of survival factors and the status of cellular transformation.

\section{Materials and methods Antibodies}

Polyclonal rabbit antibodies against $\mathrm{HSP} 90 \alpha$ were acquired from StressGen (Victoria, BC, Canada), and rabbit antiSTAT5B from Santa Cruz Biotechnology (Santa Cruz, CA, USA). Mouse anti-phospho-histone 2A.X (Ser139) clone JBW301 and anti-GRB2 antibodies (Upstate, Charlottesville, USA) and mouse anti-GRB2 (BD Biosciences, Ontario, Canada) were also acquired. GRB2 was used as a loading control [42].

\section{Plasmids}

The HSP90A-luciferase reporter gene contains about $1.8 \mathrm{~kb}$ of promoter sequences (Xho I-Hind III) of the human HSP9OA gene cloned into pLux F3 (KS89 $\alpha$ XL Lux). Expression constructs for the $\beta$-galactosidase gene, STAT5A and STAT5B [43], STAT1 and STAT3 (pME18S) and prolactin-receptor [44] have been described. The DNA encoding human HSP9OA (2199 bp, accession number [GenBank:X15183]) was amplified by PCR from cDNA prepared from SKBR3 cells (SMART cDNA synthesis kit, Clontech Laboratories, Mountain View, CA, USA). The resulting DNA was cut with Bam $\mathrm{HI}$ and Not I (New England Biolabs, Ipswich, MA, USA) (adaptors on the primers), subcloned into pcDNA 3.1/Zeo(+) behind the constitutively active cytomegalovirus immediate early promoter (CMV) and the expected sequence verified.

\section{Cell culture and cell lines}

SKBR3 cells, a human breast cancer cell line, were grown in Dulbecco's Modified Eagle Medium with L-glutamine and 10\% fetal bovine serum. Undifferentiated HC11 cells, a mouse 
mammary epithelial cell line [45], were cultured in RPMI with fetal bovine serum and maintained in $0.01 \mu \mathrm{g} / \mathrm{ml}$ epidermal growth factor (EGF) and $5 \mu \mathrm{g} / \mathrm{ml}$ insulin. Confluent cells became competent to respond to lactogenic hormones after incubation in $0.01 \mu \mathrm{g} / \mathrm{ml} \mathrm{EGF}$ for one to four days and then 5 $\mu \mathrm{g} / \mathrm{ml}$ insulin and $1 \times 10^{-7} \mathrm{M}$ dexamethasone for one day (option if treating with EGF for only one day). Differentiation was then induced (for three days if insulin and dexamethasone pre-treatment was used, or four days if not) with $1 \times 10^{-7} \mathrm{M}$ dexamethasone, $5 \mu \mathrm{g} / \mathrm{ml}$ insulin and $5 \mu \mathrm{g} / \mathrm{ml}$ prolactin. Undifferentiated $\mathrm{HC} 11$ cells were transfected with HSP9OApcDNA 3.1/Zeo(+) (HC11-HSP90 $\alpha$ ) or the empty vector pcDNA3.1/Zeo(+) (HC11-EV) using Lipofectamine 2000 (catalogue 11668-019, Invitrogen Corporation, Carlsbad, California, USA) according to the manufacturer's instructions. Transfected cells were selected as a pool with zeocin treatment and constitutive expression was verified by both northern and western blotting.

\section{Subtractive hybridisation libraries}

RNA was prepared (RNeasy, Clontech, Heidelberg, Germany) from SKBR3 cells seeded at $1 \times 10^{6}$ and $2 \times 10^{6}$ cells per 15 $\mathrm{cm}$ plate, starved of fetal bovine serum the following day for 16 hours and then treated with or without $5 \mu \mathrm{g} / \mathrm{ml}$ prolactin for 60 minutes in the presence of $10 \mathrm{nM}$ cycloheximide. The subtraction hybridisation libraries were prepared using the SMART PCR CDNA Synthesis Kit and the PCR Select Subtractive Hybridization kit (Clontech, Heidelberg, Germany), and probed using the PCR Select Differential Screening kit (Clontech, Heidelberg, Germany). Positive clones were sequenced to obtain their identity.

\section{Northern blotting}

Total RNA was extracted using peqGOLD Trifast (peqLab, Erlangen, Germany) and resolved on a formaldehyde agarose gel. The blot was blocked using ExpressHyb (Clontech, Heidelberg, Germany), and hybridised with radioactively labelled probes (Strip-EZ DNA, Ambion, AMS Biotechnology Ltd). A DNA probe encoding exon 3 of the human $C / S$ gene [46] was amplified using the forward primer 5'-GCT GGT ATT GGG GTT CC-3' and the reverse primer 5'-TGA GGG CTC TGT ACA TGA AAG-3' The fragments were gel purified (Qiaquick Gel Extraction Kit, Qiagen GmbH, Hilden, Germany).

\section{Electrophoretic mobility shift assays}

Electrophoretic mobility shift assays using a radioactively labelled fragment of the bovine $\beta$-casein promoter were performed as described [47]. Essentially the double strand STAT responsive element from the $\beta$-casein promoter was prepared and radioactively labelled before incubation with protein extracts. The complexes were resolved on a non-reducing gel and autoradiographed.

\section{Transfection and luciferase assays}

Transfection using calcium chloride and luciferase assays using HeLa cells was performed as described [48] using overnight treatments with $5 \mu \mathrm{g} / \mathrm{ml}$ prolactin. A $\beta$-galactosidase gene was included to compare transfection efficiencies in individual experiments.

\section{Western blotting}

Soluble protein extracts were prepared in a buffer containing $1 \%$ Nonidet-P-40, $50 \mathrm{mM}$ Tris pH 7.5, $5 \mathrm{mM}$ ethylene glycol tetraacetic acid and $200 \mathrm{mM}$ sodium chloride, with freshly added protease and phosphatase inhibitors: $1 \mathrm{mM}$ sodium vanadate, $20 \mu \mathrm{M}$ phenylarsine oxide, $1 \mu \mathrm{g} / \mathrm{ml}$ leupeptin, 0.5 $\mu \mathrm{g} / \mathrm{ml}$ aprotinin, $100 \mu \mathrm{M}$ phenylmethylsulphonyl fluoride and 1 $\mathrm{mM} \mathrm{DTT}$. After protein concentrations were measured with the Bio-Rad Assay, $50 \mu \mathrm{g}$ of each lysate was resolved by $15 \%$ SDS-PAGE and then transferred to Hybond-P PVDF transfer membrane (catalogue RPN303F, Amersham, GE Healthcare, Baie d'Urfé, Québec, Canada). The membrane was blocked in $5 \%$ non-fat milk in tris-buffered saline with $0.05 \%$ Tween 20 and incubated with $1 \mu \mathrm{g} / \mathrm{ml}$ of primary antibody mouse antiphospho-histone H2A.X (Ser139), clone JBW301 (Upstate, Millipore, Billerica, MA, USA) followed with horseradish peroxidase (HRP)-conjugated goat anti-mouse secondary antibody. The signal was developed by solutions prepared with $250 \mathrm{mM}$ luminal solution, $90 \mathrm{mM} \mathrm{p}$-coumaric solution, $1 \mathrm{M}$ Tris $\mathrm{pH} 8.5$ and $30 \%$ hydrogen peroxide.

\section{Apoptosis assay}

$\mathrm{HC} 11$ cells transfected with either the empty vector $\mathrm{HC} 11-\mathrm{EV}$ or with the HSP90 $\alpha$ expression construct (HC11-HSP90 $\alpha$ ) were plated at 130,000 cells/well of a 96 -well plate and differentiated as above, then starved by the absence of serum and hormones. SKBR3 cells were plated at 10,000 cells/well. The presence of mono- and oligo-nucleosomes in the cytoplasm were qualitatively measured using the Cell Death Detection Elisa Plus Kit (Roche, Mississauga, ON, Canada). Essentially, protein extracts were incubated with anti-DNA (HRP-coupled) and anti-histone (biotin coupled) antibodies, before incubation in streptavidin-coated 96-well plates. Colorimetric detection was performed at the absorbance wavelength of 405 to 490 $\mathrm{nm}$.

\section{Results \\ SKBR3 human breast carcinoma cells are responsive to prolactin through STAT5-mediated gene transcription}

To investigate the role of prolactin in breast cancer, we set out to identify prolactin responsive genes in the breast cancer cell line, SKBR3. We first examined the prolactin-based activation of STAT5 and the induction kinetics of previously identified STAT5-dependent genes. SKBR3 cells were treated with different doses of prolactin and the activated DNA-binding form of STAT5 was visualised in electrophoretic mobility shift assays (Figure 1a). The experiment shows that prolactin is able to activate STAT5 in SKBR3 cells in a dose-dependent 
Figure 1

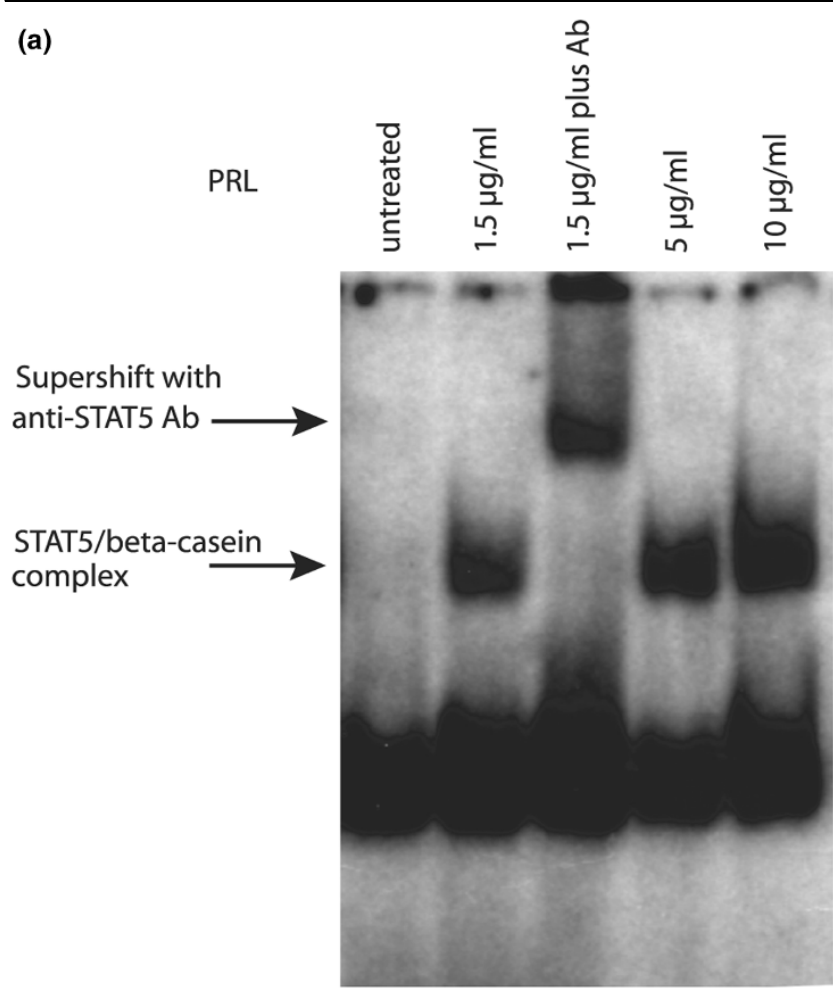

(b)

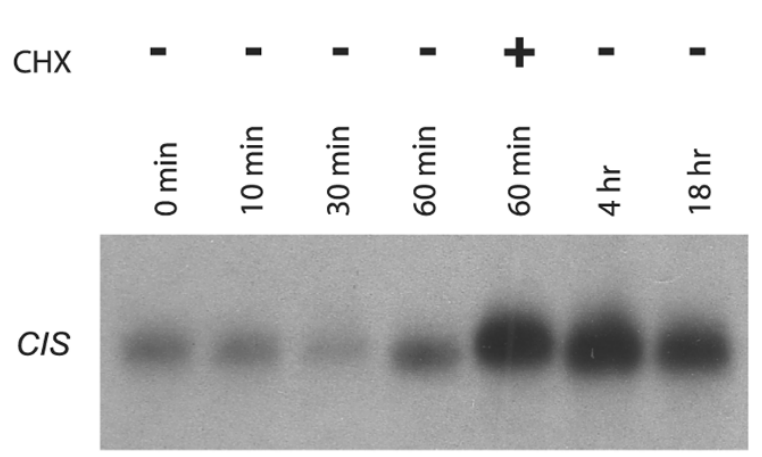

GAPDH

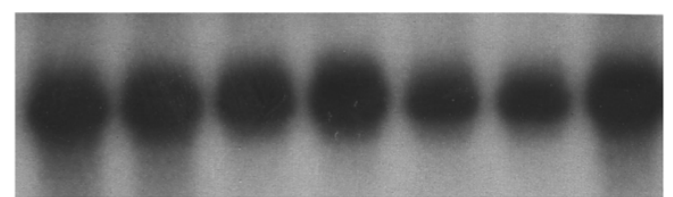

Prolactin-STAT5-mediated signal transduction in SKBR3 cells. (a) Electrophoretic mobility shift assays were carried out with a radioactively labelled $\beta$-casein gene promoter probe and protein extracts of SKBR3 cells treated for one hour with the indicated amounts of prolactin (PRL). The arrows indicate the positions of the signal transducers and activators of transcription (STAT5) DNA complex and of a supershifted complex formed in the presence of a STAT5 specific antibody (Ab). (b) SKBR3 cells were seeded one day, the next day starved of serum overnight and the following day were stimulated (or not) with 5 $\mu \mathrm{g} / \mathrm{ml}$ prolactin for the times indicated in the absence of cycloheximide $(\mathrm{CHX})$ unless indicated. In each lane $20 \mu \mathrm{g}$ of RNA were applied. The northern blot was first hybridised with labelled DNA encoding cytokine inducible $\mathrm{SH} 2$ containing protein $(\mathrm{C} / \mathrm{S})$ and then rehybridised with a glyceraldehyde 3-phosphate dehydrogenase (GAPDH) specific probe. manner. A STAT5 specific antibody was used to confirm the specificity of the protein-DNA complex (Figure 1a). Prolactin stimulation of 60 minutes resulted in activation and binding of STAT5 to DNA response elements present in the $\beta$-casein promoter. Of note is the lack of STAT5 activation in the absence of prolactin stimulation. SKBR3 cells have previously been shown to express the prolactin gene [49], but perhaps the endogenous levels of prolactin are not sufficient to induce activation of the JAK2-STAT5 pathway.

We next followed the kinetics of cytokine-inducible-SH2-containing protein $(C / S)$ mRNA induction as a function of prolactin treatment of SKBR3 cells. The CIS gene [50] is a known target of the JAK2-STAT5 pathway activated by interleukin-2 or erythropoietin in lymphoid cells and is important for feedback inhibition [51,52]. The amount of $C / S$ mRNA increased within 60 minutes of treatment and was further enhanced in the presence of cycloheximide, an inhibitor of protein synthesis (Figure 1b). The level of $C / S$ mRNA reached a maximum at four hours and remained high for at least 18 hours. This confirmed that SKBR3 cells are appropriate to study the early induction of prolactin-JAK2-STAT5-regulated genes and that a time point of 60 minutes would result in the production of early target genes.

\section{Prolactin-regulated genes in SKBR3 breast cancer cells}

To identify additional genes regulated by prolactin in SKBR3 cells, we prepared subtraction hybridisation libraries. Based on the above observations, SKBR3 cells were treated for 60 minutes with $5 \mu \mathrm{g} / \mathrm{ml}$ prolactin and the RNA was used for preparation of the subtractive hybridisation libraries. Cycloheximide was added to cell preparations, both untreated and treated with prolactin in order to avoid identification of secondary targets. We prepared subtraction libraries for the genes differentially expressed on prolactin treatment (forward) and for genes expressed in the absence of prolactin (reverse). The two libraries were used in the differential screen for prolactinregulated genes. About 1200 gene fragments were screened from the forward library and 770 from the reverse library. Genes were screened using Southern blotting in batches of 100 genes using the forward and reverse libraries as probes. The genes with the most intense differential signal on each blot, as measured using a Biorad phosphoimager (Bio-Rad, Munich, Germany), were selected for sequencing. Seventytwo positive clones selected on the basis of high expression in the forward (Table 1) or reverse libraries (Table 2) were sequenced and identified. Some genes were observed more than once (Tables 1 and 2), also indicating high differential expression. Of the 51 genes represented, 19 genes with the highest expression levels were rescreened in dot-blots using both the unsubtracted probes (cDNA) and subtracted probes and the expression patterns of 16 of the 19 genes were confirmed (86\%) (Tables 1 and 2). 
Table 1

Forward library - Genes upregulated in the presence of prolactin

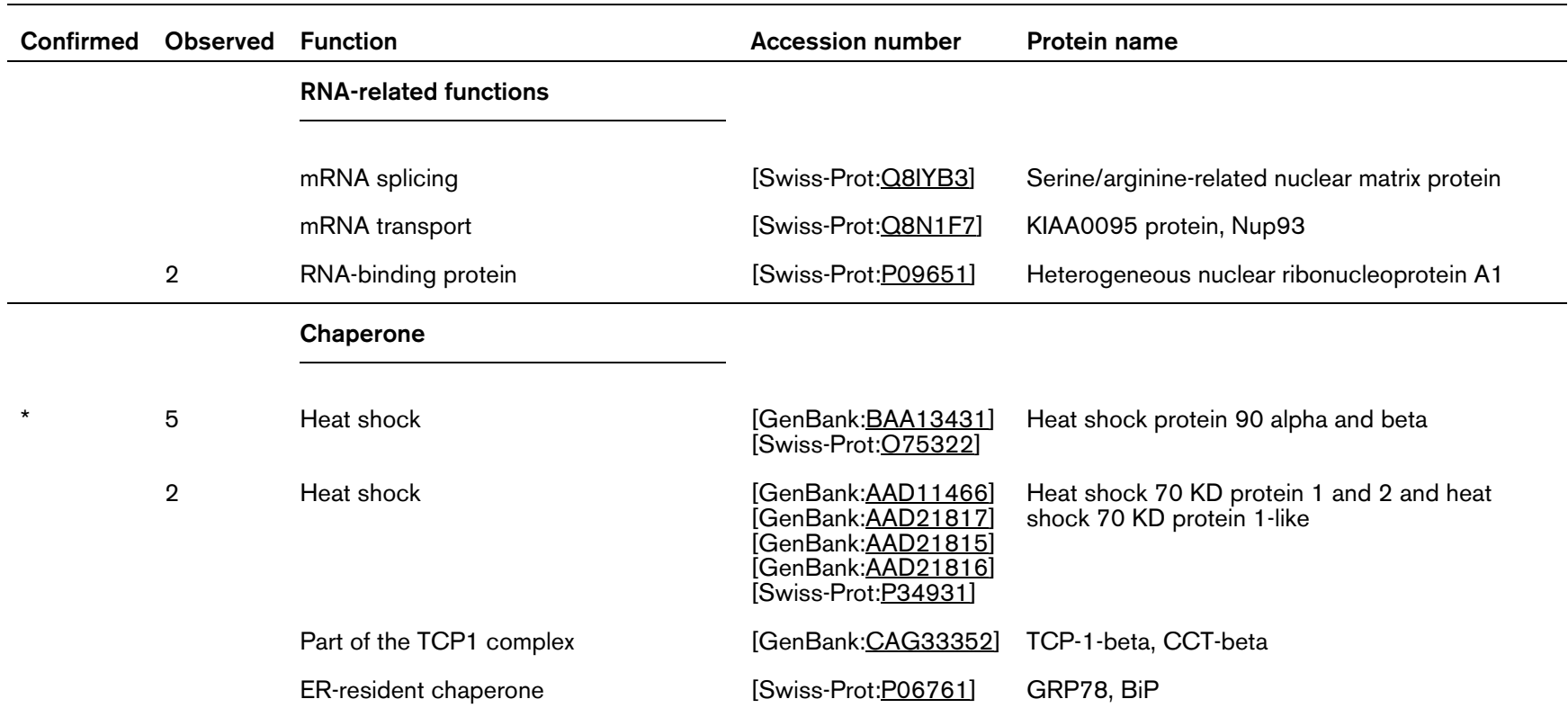

\section{Protein synthesis}

\begin{tabular}{|c|c|c|c|c|}
\hline \multirow[t]{2}{*}{ * } & \multirow[t]{2}{*}{5} & Protein synthesis & [Swiss-Prot:14222] & Elongation factor- 1 alpha \\
\hline & & Upregulated in metastasis & [Swiss-Prot:Q9NQ50] & $\begin{array}{l}\text { 39S ribosomal protein } L 40 \text {, mitochondrial } \\
\text { precursor, L40mt, MRP-40 }\end{array}$ \\
\hline \multirow{9}{*}{ * } & \multirow{4}{*}{2} & Electron transport & & \\
\hline & & Oxidative phosphorylation & [GenBank:AAD13930] & $\begin{array}{l}\text { Mitochondrial hinge protein, OXPHOS system } \\
\text { complex III mitochondrial subunit }\end{array}$ \\
\hline & & Mitochondrial electron transport chain & [Swiss-Prot:Q15070] & $\begin{array}{l}\text { inner membrane protein } \mathrm{OXA} 1 \mathrm{~L} \text {, mitochondrial } \\
\text { precursor }\end{array}$ \\
\hline & & Mitochondrial electron transport chain & [GenBank:BAA77673] & NADH dehydrogenase subunit 4 \\
\hline & & Transport & \multirow[b]{2}{*}{ [Swiss-Prot:075935] } & \multirow[b]{2}{*}{$\begin{array}{l}\text { Dynactin subunit } 3 \text {, dynactin complex subunit } 22 \\
\text { kDa subunit, p22 }\end{array}$} \\
\hline & & ER-to-Golgi transport & & \\
\hline & & Proteasome & & \\
\hline & & $\begin{array}{l}\text { Regulatory subunit of proteasome } \\
\text { function }\end{array}$ & [Swiss-Prot:Q13041] & $\begin{array}{l}26 \mathrm{~S} \text { proteasome regulatory subunit } \mathrm{S} 2, \mathrm{p} 97 \\
\text { tumour necrosis factor type } 1 \text { receptor-associated } \\
\text { protein } 2\end{array}$ \\
\hline & & Proteasome & [Swiss-Prot:P25789] & $\begin{array}{l}\text { Proteasome component } \mathrm{C} 9 \text {, macropain subunit } \\
\mathrm{C} 9\end{array}$ \\
\hline
\end{tabular}

Ubiquitination

Heterodimerising with cullin-1 to catalyse ubiquitin polymerisation

[GenBank:AAD29715] Ring box protein 1

Survival

* Survival

[GenBank:AAB87479] TEGT protein, BAX inhibitor 1 


\begin{tabular}{|c|c|c|c|c|}
\hline * & 2 & Caspase-9 inhibition & [Swiss-Prot:000165] & $\mathrm{HA} 1$-associating protein $\mathrm{Hs} 1$-binding protein \\
\hline & & \multicolumn{3}{|l|}{ Miscellaneous } \\
\hline & & Activity in milk & [Swiss-Prot:P07195] & L-lactate dehydrogenase $\mathrm{H}$ chain $\mathrm{LDH}-\mathrm{B}$ \\
\hline & 2 & ECM-receptor interaction & [GenBank:BAA76814] & $\begin{array}{l}\text { KIAA0970 protein, fibronectin type III domain } \\
\text { containing } 3 \mathrm{~A}\end{array}$ \\
\hline & & $\begin{array}{l}\text { Toll-like receptor-mediated interferon } \\
\text { response }\end{array}$ & [GenBank:AAD34590] & T2K protein kinase homolog (mouse) \\
\hline \multirow[t]{5}{*}{ * } & 2 & Iron storage & [Swiss-Prot:P02794] & Ferritin heavy chain, ferritin $\mathrm{H}$ subunit \\
\hline & & Endosome location & [Swiss-Prot:0.99805] & $\begin{array}{l}\text { Transmembrane } 9 \text { superfamily protein member } 2 \\
\text { precursor, p76 }\end{array}$ \\
\hline & & Regulation of nonmuscle myosin II & [Swiss-Prot:014950] & Myosin regulatory light chain \\
\hline & & nucleic acid synthesis & [Swiss-Prot:P30085] & UMP-CMP kinase 1 , cytidylate kinase \\
\hline & & Retaining proteins in the ER & [Swiss-Prot: $\underline{0.08013]}$ & TRAP gamma, SSR-gamma \\
\hline * & & Peptide-modifying enzyme component & [Gi:2894085] & $\begin{array}{l}\text { P40 mRNA for lanthionine synthetase C-like } \\
\text { protein } 1\end{array}$ \\
\hline
\end{tabular}

Prolactin-regulated genes. cDNA fragments identified preferentially in the forward library (presence of prolactin) was sequenced. Sequences that were identical to those that encoded human proteins are presented using the protein accession number. Genes that were identified more than once are indicated as the number of times observed. Genes that were confirmed by a second screen are marked with an asterisk. $\mathrm{BAX}=\mathrm{Bcl}$ 2-associated $\mathrm{X}$ protein; $\mathrm{BiP}=$ binding protein; $\mathrm{CCT}$-beta = chaperonin-containing TCP-1 complex; UMP-CMP = citidine monophosphate; ER = endoplasmic reticulum; GRP78 = 78 KD glucose-regulated protein precursor; $\mathrm{NADH}=$ nicotinamide adenine dinucleotide plus hydrogen; Nup93= nuclear pore complex protein; NF45 = nuclear factor of activated T-cells $45 \mathrm{kDa}$; OXA1L = oxidase assembly 1 -like protein; OXPHOS = oxidative phosphorylation; TCP-1-beta = T-complex protein 1, beta subunit; TEGT = testis enhanced gene transcript; TRAP gamma $=$ translocon-associated protein, gamma subunit; SSR-gamma = signal sequence receptor gamma subunit.

Although there were no pre-existing large studies of prolactinregulated genes in breast cancer cells, we compared our results with other prolactin-related studies. Of note, 11 of the genes we identified overlapped with those previously identified as downstream targets of the prolactin pathway. In one study, prolactin gene targets were identified by gene array using regenerated mammary glands from prolactin-receptor-/and cyclin D-/- mammary epithelial cell transplants. Cyclin D1 was thought to represent a secondary target of prolactin, and therefore genes identified in this screen would represent effectors downstream of prolactin and upstream of cyclin D1 [18]. Although the transplants were nontransformed cells, unlike SKBR3 cells, we noted some similarities. Genes that were identical in this study and our report include the genes encoding the mouse ferritin heavy chain gene, HSPs 70, 71 and 84 (HSP9OB). We also found overlap with prolactin-regulated genes identified in the rat $\mathrm{Nb2}$-11c lymphoma cell line [53], including HSP70 and HSP86 (HSP9OA). Genes found to be similar (either functionally related or different subunits of a complex) between these two studies and ours include Sec 23 [18] and Sec 22 [53] (similar to Sec 24 in our study), elongation factor 2 [18,53] (similar to elongation factor 1 alpha), lactate dehydrogenase $1 \mathrm{~A}$ chain [18] (similar to lactate dehydrogenase $\mathrm{H}$ chain), myosin heavy chain (similar to myosin regulatory light chain), T-complex protein $1 \mathrm{e}$ and h subunits [53] (similar to T-complex b subunit). The degree of overlap with the prolactin-regulated genes of these two studies is comparable with the level previously described between other prolactin target gene studies [19]. The diversity of the gene lists found in each study is thought to derive from the differences between experimental conditions, cell types and methods.

\section{HSP90A is a prolactin-induced gene in SKBR3 human breast cancer cells}

The gene HSP9OA was identified five times in the initial group selected for sequencing; and based on its high representation, differential expression and its function in cancer cells, was used for further analysis.

We used northern blotting analysis to independently verify the induction of the HSP9OA gene in SKBR3 cells by prolactin. We plated cells at two different confluences (about $40 \%$ and $60 \%$ confluent on the day of stimulation) as was performed for the preparation of the library. Both populations responded to 60 minutes of prolactin treatment with the increase in HSP9OA mRNA, but the dose response of HSP9OA induction in the two-cell population was distinguishable. Cells at the higher confluence exhibited a maximal response at $1.5 \mu \mathrm{g} / \mathrm{ml}$, whereas cell at lower confluence required $5 \mu \mathrm{g} / \mathrm{ml}$ for maximal induction (Figure 2a). Higher concentrations of prolactin reduce the maximal response. The observed lower level of total RNA in high confluence cells treated with $10 \mu \mathrm{g} / \mathrm{ml}$ prolactin, and potentially the inhibitory presence of $C / S$, may 
Table 2

Reverse library - Genes upregulation in the absence of prolactin

\begin{tabular}{|c|c|c|c|c|}
\hline Confirmed & Observed & Function & Accession number & Protein name \\
\hline & & RNA-related functions & & \\
\hline & & Splicing factor & [Swiss-Prot:075533] & $\begin{array}{l}\text { Splicing factor } 3 B \text { subunit } 1 \text {, spliceosome- } \\
\text { associated protein } 155\end{array}$ \\
\hline & & Translational regulation & [Swiss-Prot:Q8TB72] & Pumilio homolog 2, pumilio-2, KIAA0235 fragment \\
\hline & & Chaperone & & \\
\hline & & Chaperone & [Swiss-Prot:060925] & Prefoldin subunit 1 \\
\hline \multirow{6}{*}{ * } & & Protein synthesis & & \\
\hline & & Activates the trk oncogene & [Swiss-Prot:P62424] & $\begin{array}{l}\text { 60S ribosomal protein } L 7 A \text {, surfeit locus protein } 3 \text {, } \\
\text { PLA-X polypeptide }\end{array}$ \\
\hline & & Electron transport & & \\
\hline & & Electron transport & [GenBank:AAC25442] & $\mathrm{NADH}$ dehydrogenase subunit 2 homo sapiens \\
\hline & & $\begin{array}{l}\text { Selenium metabolism and } \\
\text { protection oxidative stress }\end{array}$ & [Swiss-Prot:Q99475] & $\begin{array}{l}\mathrm{Km}-102-\text { derived reductase like factor, thioredoxin } \\
\text { reductase }\end{array}$ \\
\hline & & Electron transport & $\begin{array}{l}\text { [RefSeq:NP_055217] + } \\
\text { [GenBank:EAW62308] } \\
{[\text { [GenBank:AAH90048] }} \\
{[\text { [GenBank:AAH01390] }} \\
{[\text { [Swiss-Prot:O14949] }}\end{array}$ & $\begin{array}{l}\text { Ubiquinol-cytochrome c reductase complex } \\
\text { ubiquinone binding protein QP-C, complex III } \\
\text { subunit VII }\end{array}$ \\
\hline
\end{tabular}

Transport

*

Vesicle trafficking protein transport

[GenBank:BAA07558]

Hypothetical protein KIAA0079, HA3543, SEC24related protein $\mathrm{C}$

*

Protein transport

[GenBank:CAl15005]

Coatomer alpha subunit, Alpha-COP

Proteasome

* Proteasome [Swiss-Prot:P25788

Proteasome component C8, macropain subunit C8, proteasome subunit alpha type 3 multicatalytic endopeptidase complex subunit C8

\section{Ubiquitination}

Deubiquitinating enzyme tumour suppressor

Ubiquitin-specific protease cysteine proteases
* Ubiquitin cycle

[GenBank:BAA74872]

[GenBank:AAH64516]

[GenBank:NP 005144]

[Swiss-Prot:Q14694]

[GenBank:ABM86690]

[GenBank:ABM83479]
[Gl:4929720]

[GenBank:NP 057490]

[Swiss-Prot:Q9Y3C8]

[GenBank:AF151884]
KIAA0849 protein, CYLD gene

KIAA0190 ubiquitin specific peptidase 10

Ubiquitin-fold modifier conjugating enzyme 1 
Reverse library - Genes upregulation in the absence of prolactin

\begin{tabular}{|c|c|c|c|c|}
\hline \multirow{3}{*}{ * } & & Transcription factors & \multirow[b]{2}{*}{ [Swiss-Prot:Q12905] } & \multirow[b]{2}{*}{ Interleukin enhancer-binding factor $2, \mathrm{NF} 45$ protein } \\
\hline & & Transcription factor & & \\
\hline & & $\begin{array}{l}\text { Transcription factor complex, RNA } \\
\text { binding }\end{array}$ & [GenBank:CAA10029] & NS1-binding protein \\
\hline & & Miscellaneous & & \\
\hline \multirow[t]{7}{*}{ * } & 2 & $\begin{array}{l}\mathrm{N} \text {-oligosaccharyl transferase } \\
\text { complex }\end{array}$ & [GenBank:CAB41763] & DJ343K2.2.1, ribophorin II isoform 1 \\
\hline & & Unknown & [Swiss-Prot:095801] & Tetratricopeptide repeat protein 4 \\
\hline & & Kinase & [GenBank:BAA76815] & KIAA0971 protein, FAST kinase domains 2 \\
\hline & & Mitochondrial fusion & $\begin{array}{l}\text { [Swiss-Prot:O95140] } \\
\text { [GenBank:AAD02058] }\end{array}$ & MFN2, KIAA0214 protein, CPRP1 \\
\hline & & Calcium binding & [Swiss-Prot:P62158] & Calmodulin \\
\hline & & $\begin{array}{l}\text { Glycolytic and gluconeogenesis } \\
\text { pathways Second product- } \\
\text { transcription factor }\end{array}$ & [Swiss-Prot:P06733] & $\begin{array}{l}\text { Alpha-enolase, 2-phospho-D-glycerate hydro-lyase, } \\
\text { enolase 1, MBP-1, plasminogen-binding protein }\end{array}$ \\
\hline & 2 & $\begin{array}{l}\text { Palmitoyl-(protein) hydrolase } \\
\text { activity }\end{array}$ & [PIR:I58097] & $\begin{array}{l}\text { Palmitoyl protein thioesterase precursor, EC } \\
3.1 .2 .22\end{array}$ \\
\hline * & & Iron ion transport & [GenBank:gi:37432] & Transferrin receptor, p90, CD71 \\
\hline * & 2 & $\begin{array}{l}\text { Unknown OR Wnt signalling } \\
\text { pathway }\end{array}$ & $\begin{array}{l}\text { [GenBank:gi:1167502] } \\
\text { [GenBank:gi:1524104] }\end{array}$ & Hypothetical protein $\mathrm{TI}-227 \mathrm{H}$ wnt 13 \\
\hline \multicolumn{5}{|c|}{$\begin{array}{l}\text { Prolactin-regulated genes. cDNA fragments identified preferentially in the reverse libraries (absence of prolactin) were sequenced. Sequences } \\
\text { that were identical to those that encoded human proteins are presented using the protein accession number. Genes that were identified more } \\
\text { than once are indicated as the number of times observed. Genes that were confirmed by a second screen are marked with an asterisk. } \\
\text { Alpha-COP = alpha coat protein; CPRP } 1=\text { caprine prolactin-related protein- } 1 \text {; CYLD = cylindromatosis; FAST = Fas-activated serine/threonine; } \\
\text { MFN } 2=\text { mitofusin-2, transmembrane GTPase; MBP- } 1=\text { C-myc promoter-binding protein; NADH = nicotinamide adenine dinucleotide plus } \\
\text { hydrogen; NS } 1=\text { non-structural } 1 \text { protein; NF45 = nuclear factor of activated T-cells } 45 \text { kDa; wnt } 13=\text { wingless-type MMTV (mouse mammary } \\
\text { tumour virus) integration site family, member } 2 B \text {. }\end{array}$} \\
\hline
\end{tabular}

explain the reduction in signal observed in higher confluence cells at $10 \mu \mathrm{g} / \mathrm{ml}$. Another alternative is that the high concentration of prolactin induced a refractory state of prolactin signal transduction [54]. These results confirm that the HSP9OA gene is a prolactin-regulated gene in the human mammary carcinoma cell line, SKBR3.

We then investigated whether there was an increase in the encoded protein HSP90 $\alpha$ in prolactin-treated SKBR3 cells. SKBR3 cells were cultured in the absence or presence of prolactin and protein extracts were resolved by SDS-PAGE. Western blotting using antibodies directed against $\mathrm{HSP} 90 \alpha$ indicated that there is a two-fold increase in the amount of HSP90 $\alpha$ protein in prolactin treated cells (Figure 2b). Prolactin therefore induces both the expression of HSP90A mRNA and increases HSP9O $\alpha$ protein in breast cancer cells.

We also investigated the response of the HSP9OA gene in mouse mammary epithelial HC11 cells. $\mathrm{HC} 11$ cells exist in an undifferentiated state until competent cells are stimulated appropriately with lactogenic hormones, dexamethasone, insulin and prolactin, to differentiate and produce milk proteins [55]. We compared the levels of HSP9OA mRNA in HC11 cells in their undifferentiated state and after a one-hour treatment of competent cells with lactogenic hormones, including prolactin (Figure 2c), simulating the time point used in SKBR3 cells. Lactogenic hormone induction resulted in a rapid fourfold increase of HSP9OA mRNA in $\mathrm{HC} 11$ cells, as quantified by phosphoimager analysis of northern blots using actin as a loading control. We also observed up to a two-fold increase in HSP90 $\alpha$ protein, peaking at 48 hours of lactogenic hormone induction of HC11 cells (Figure 2d). This demonstrated that the HSP90A mRNA and protein are elevated during early mammary epithelial cell differentiation in response to lactogenic hormones.

\section{The promoter of the HSP90A gene is preferentially activated by STAT5B}

Inspection of the human HSP9OA gene upstream sequence indicated the presence of at least two potential STAT-binding DNA elements that could bind STAT1, STAT3 or STAT5 [56] (nucleotides 1611-1603 and 1177-1185, [Gen- 
Figure 2

(a)

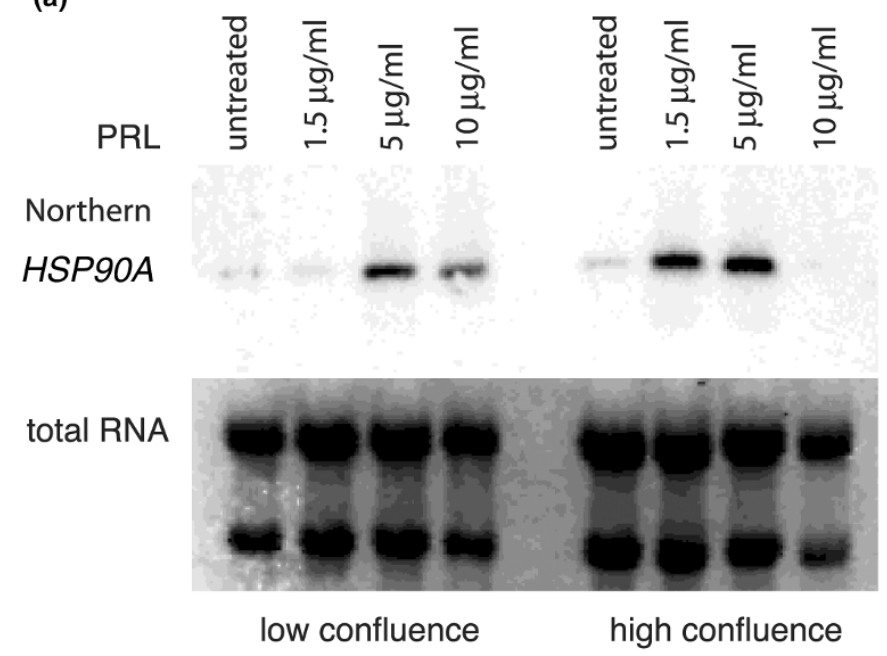

(b) Western

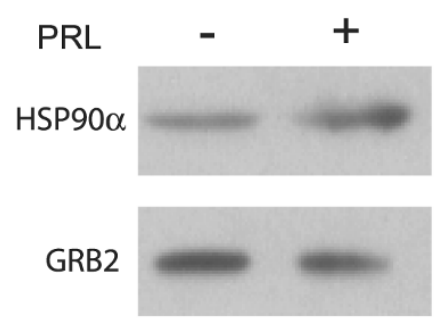

(c)

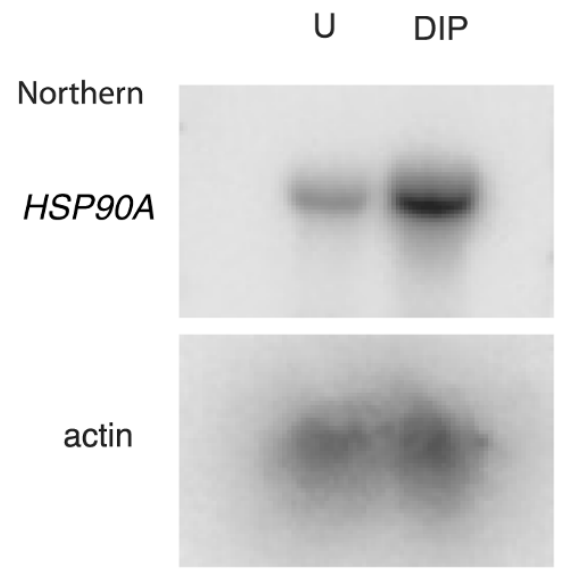

Time course

(d)

of differentiation

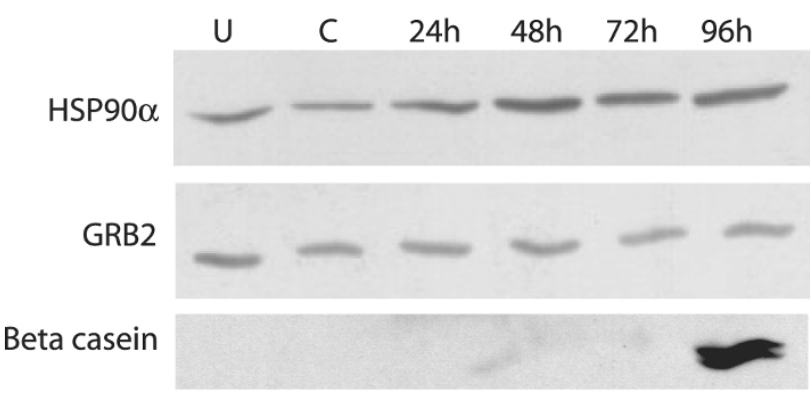

HSP90 $\alpha$ is a prolactin regulated target gene. (a) Dose response of the heat shock protein 90 alpha (HSP90A) gene to prolactin in SKBR3 cells assessed by northern analysis. SKBR3 cells were seeded to achieve low and higher confluence before treatment for one hour with the indicated doses of prolactin (PRL). Total RNA was transferred to a nylon membrane, and the blot probed with the HSP9OA gene fragment. (b) Western blot analysis: HSP90 $\alpha$ protein is increased about two-fold in SKBR3 cells in response to $5 \mathrm{ug} / \mathrm{mL}$ prolactin. (c) Northern analysis: HSP90 $\alpha$ mRNA is increased about four-fold in HC11 cells in response to a one hour treatment of lactogenic hormones, prolactin, dexamethasone and insulin (DIP) compared with undifferentiated (U) $\mathrm{HC} 11$ cells treated with epidermal growth factor and insulin. (d) Western blot of HSP90 $\alpha$ protein extracts from undifferentiated, competent (C) HC11 cells or after DIP treatment for the time indicated. Production of beta-casein is observed after 96 hours when the cells are fully differentiated. Longer exposures show a small amount of beta-casein after 72 hours.

Bank:U25822]). Although STAT1 and STAT3 have been reported to respond to prolactin, the prolactin signal is mainly conferred through the activation of STAT5A and STAT5B, two highly homologous members of the STAT family [57]. In order to investigate the prolactin responsiveness of the HSP9OA gene promoter, we conducted reporter assays using a gene construct containing about $1.8 \mathrm{~kb}$ of the human HSP9OA upstream regulatory sequence fused to a luciferase reporter gene. We transfected HeLa cells with expression vectors for the long form of the human prolactin-receptor, the HSP9OAluciferase reporter construct and various STATs.

Prolactin activation of cells transfected with STAT5B, or STAT5A and STAT5B together, caused over a four-fold or an over two-fold increase in luciferase activity, respectively, when compared with cells without exogenous STAT5 expression (Figure $3 \mathrm{a}$ ). As the induction in the presence of exogenous STAT5A alone was not statistically significant, the significance of the STAT5A/5B result may be due to the presence of STAT5B. The smaller effect of the combination of STAT5A/5B over STAT5B alone may be due to the sequestering of STAT5B through the formation of heterodimers. We also performed reporter assays in both COS-7 as well as SKBR3 cells and obtained similar results with respect to the preferential transcription of the reporter by STAT5B rather than STAT5A (data not shown). In HeLa cells, a small effect of STAT1 and no effect of STAT3 on luciferase activity were observed (Figure $3 b)$. STAT5B is the predominant form of STAT5 in breast tumour cell lines including SKBR3 [58] and most likely contributes to the elevated expression of HSP90 $\alpha$ in breast cancer 
Figure 3

(a)

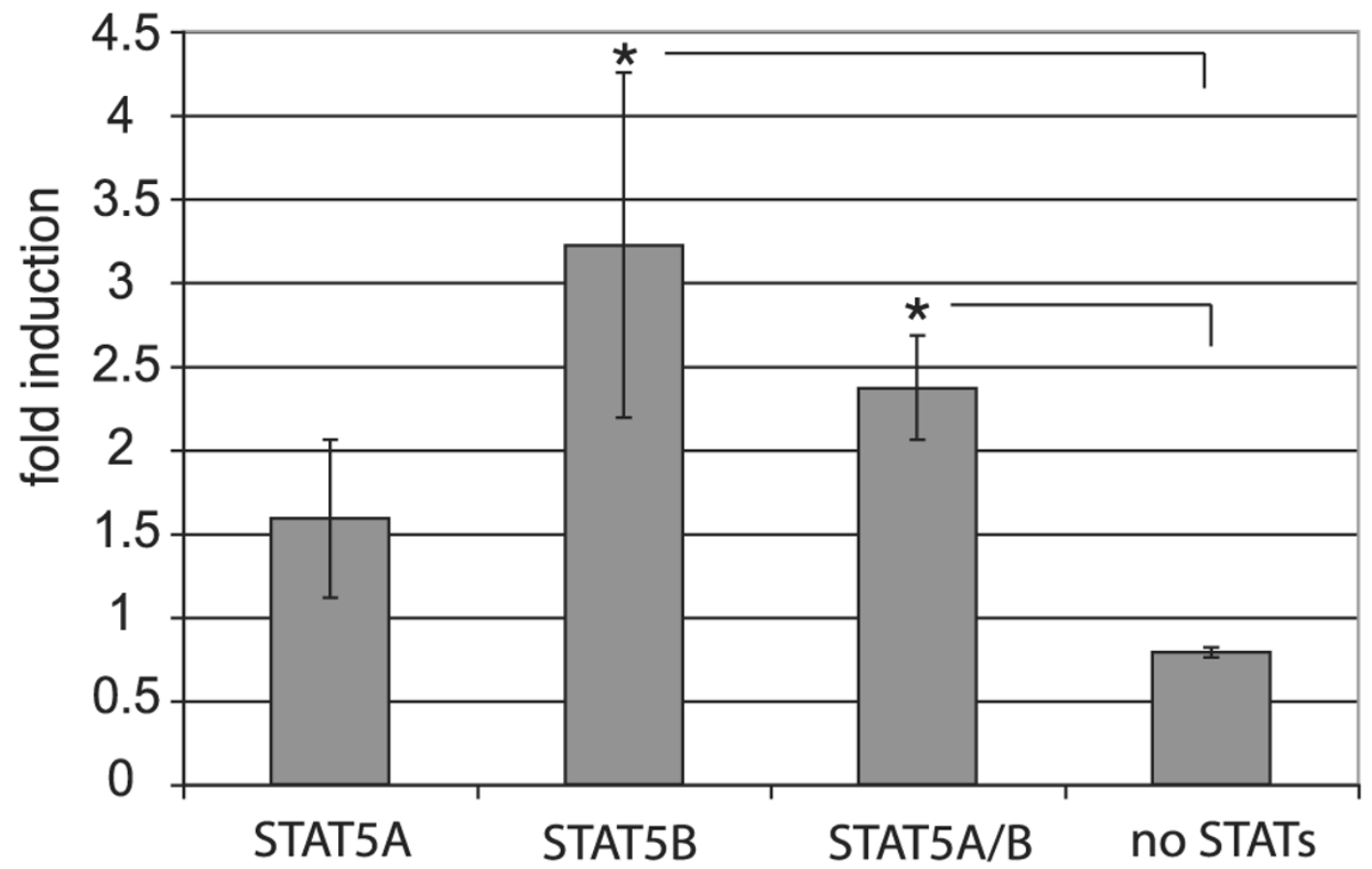

(b)

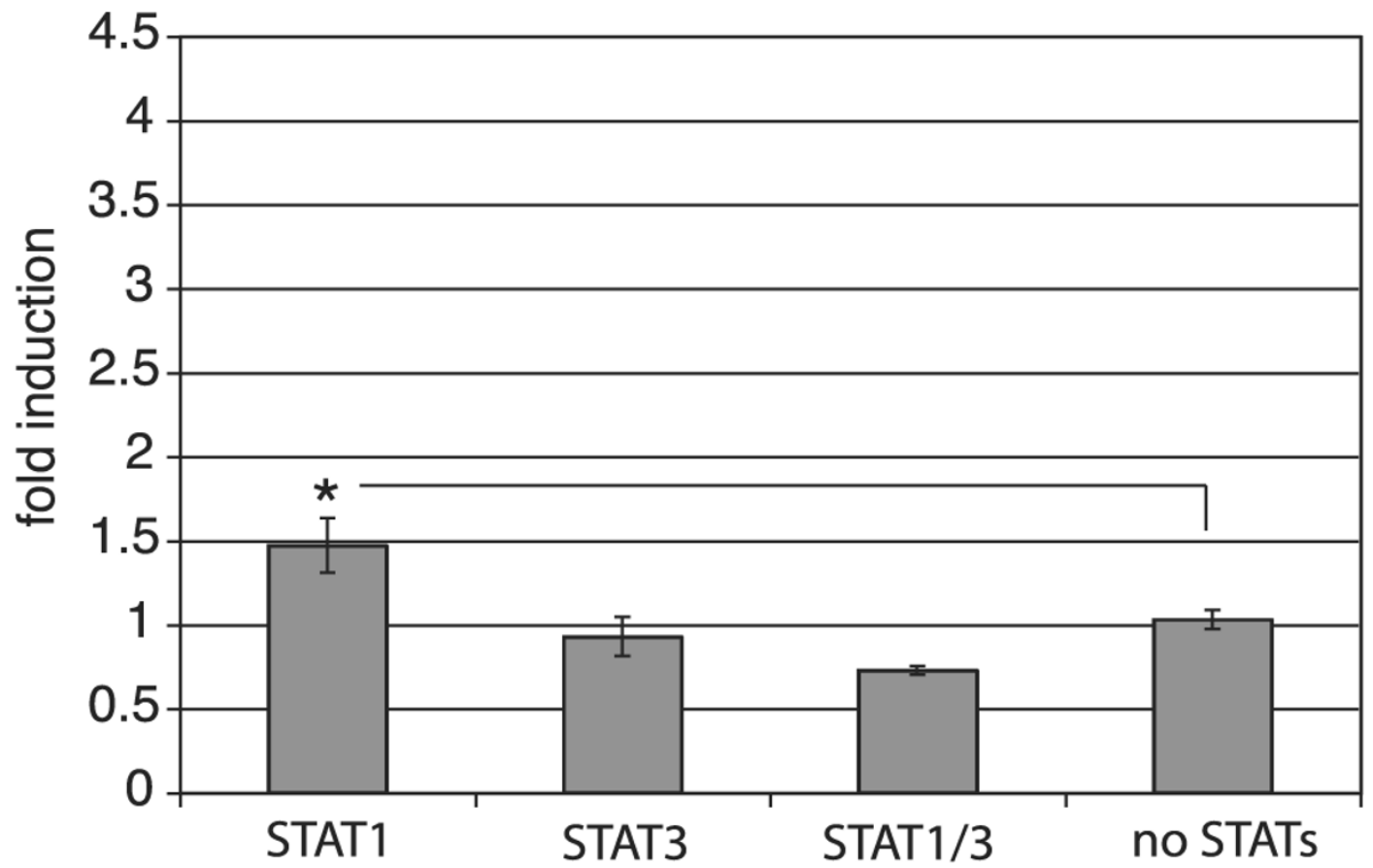

Prolactin-STAT5 induction of a HSP9OA promoter-luciferase reporter gene. HeLa cells were transiently cotransfected with DNA encoding the prolactin-receptor, the indicated signal transducers and activators of transcription (STATs), the heat shock protein 90 alpha (HSP90A)-luciferase reporter and $\beta$-galactosidase. Luciferase assays were performed 48 hours post transfection and the luciferase activity values normalised with $\beta$ galactosidase levels. Fold induction was calculated using the normalised luciferase activity from transfected cells in the absence of prolactin. An asterix indicates that the results are significantly different $(p<0.05 \mathrm{t}$-test) compared with the sample with no STAT proteins. Each bar represents the average of three to five experiments with standard deviation. (a) STAT5A and/or STAT5B. (b) STAT1 and/or STAT3. 
cells. These reporter assays confirm that HSP90A is a prolactin-STAT5 regulated target gene.

\section{Prolactin acts as a survival factor in differentiated HC11 cells}

Following the line of reasoning that prolactin acts as a survival factor in breast cancer cells [59-63] and that STAT5 promotes survival in normal mammary epithelial cells $[64,65]$, we tested whether the addition of prolactin to starved, untransformed mammary epithelial HC11 cells would rescue differentiated cells from apoptosis. HC11 cells were induced to differentiate after they reached confluence by the addition of the lactogenic hormones prolactin, dexamethasone and insulin. Differentiated HC11 cells were then starved of serum and lactogenic hormones with individual hormones returned as indicated for 72 hours, followed by analysis of mono- and oligo-nucleosomes as an indicator of apoptosis (Figure 4). Serum and hormone withdrawal of $\mathrm{HC} 11$ cells is known to induce apoptosis [66]. Each of the lactogenic hormones, including prolactin, greatly protects $\mathrm{HC} 11$ cells equally well from apoptosis when serum and other lactogenic hormones are removed.

\section{Constitutive HSP90A expression sensitises mammary epithelial cells to apoptosis in starved HC11 cells}

We reasoned that $\mathrm{HSP} 90 \alpha$ would have important functions downstream of prolactin not only in cancerous breast cells, but also in untransformed mammary epithelial cells, such as $\mathrm{HC} 11$. For this purpose, we created $\mathrm{HC} 11$ cell lines that either constitutively expressed the gene for human HSP90 $\alpha$ $(\mathrm{HC} 11-\mathrm{HSP} 90 \alpha)$ or carried the empty vector (HC11-EV). There is a two-fold increase in HSP9O $\alpha$ in the HC11-HSP90 $\alpha$ line. Given that we showed that prolactin is a survival factor in $\mathrm{HC} 11$ cells, we then investigated whether the HC11-HSP90 $\alpha$ cells were susceptible to apoptosis induced by the removal of prolactin and other survival factors. We used two independent methods.

First, we used an antibody against phosphorylated-histone 2A.X as a marker of the apoptotic DNA damage [67] that occurs in response to starvation. As expected, there was little to no indication of phosphorylated-histone $2 A . X$ in the undifferentiated, competent or differentiated cells, which are cultured in the presence of serum and hormones (Figure 5a). Differentiated cells were then starved of serum and all lactogenic hormones for up to 48 hours to induce apoptosis. The HC11HSP90 $\alpha$ cell lines were more sensitive to starvation than the parental HC11 cells or cells expressing the empty vector. After 24 hours of serum and hormone withdrawal, phospho-histone $2 \mathrm{~A} . \mathrm{X}$ is easily detected by western blot in the HC11-HSP90 $\alpha$ cells, but not as easily in the control HC11 cells (Figure $5 \mathrm{~b}$ ) or cells carrying the empty vector (HC11-EV) (not shown as the response was similar).

We then investigated whether the amount of HSP90 $\alpha$ differs between the differentiated and starved cells. When cells are starved for 24 hours, the amount of HSP90 $\alpha$ in control cells

Figure 4

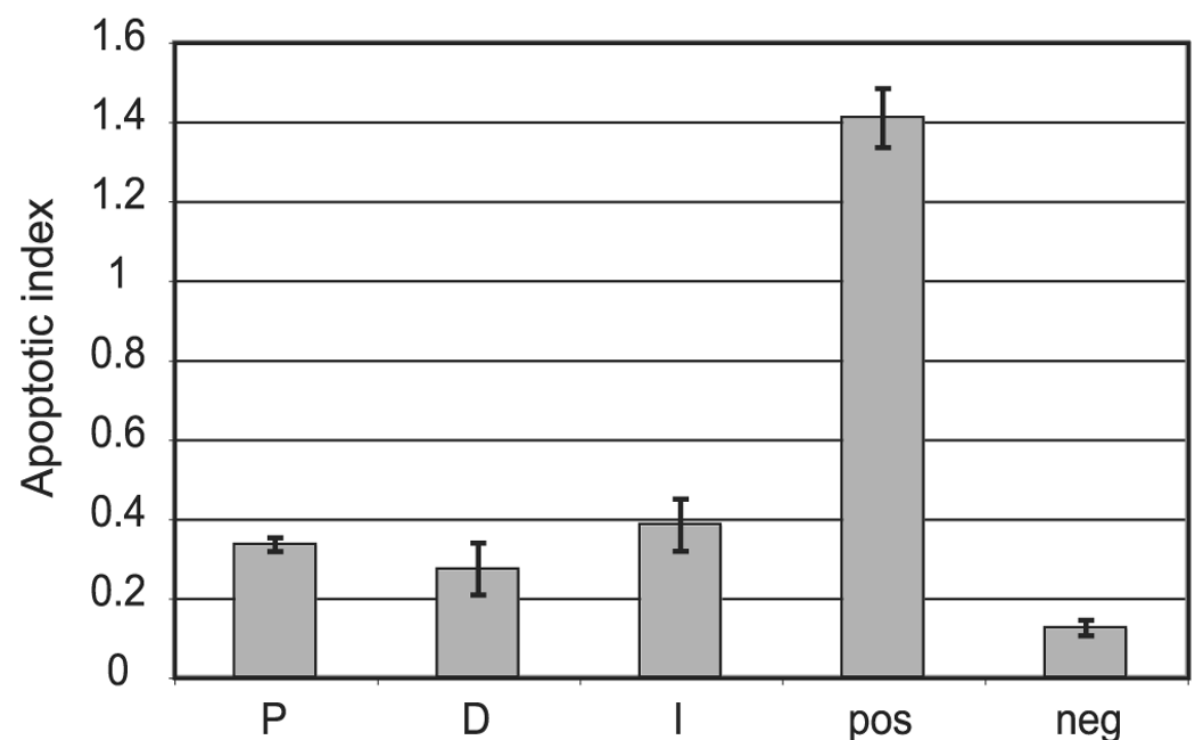

Prolactin is a survival factor for HC11 cells. Differentiated HC11 cells were starved of serum and hormones and with specific hormones added back alone as indicated. After 72 hours, cytoplasmic extracts were prepared and analysed by sandwich ELISA for apoptotic mono- and oligo-nuclesomes. All rescue treatments of prolactin (P), dexamethasone (D) or insulin (I) significantly reduced apoptosis caused by starvation of hormones and serum (pos), for example, between prolactin rescue and positive control, $p=0.001$ in a t-test. Negative control (neg) are cells in differentiation medium (DIP) without starvation. Each bar represents the average of three experiments with standard deviation. 
Figure 5

(a)
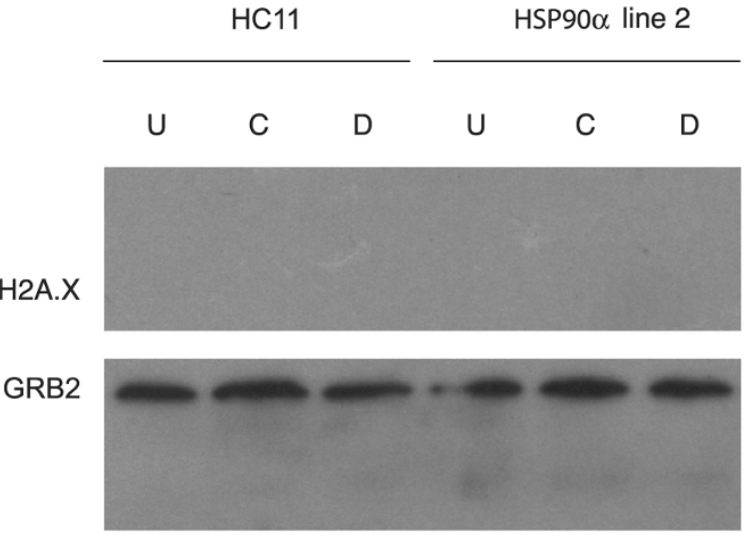

(b)

24 hours

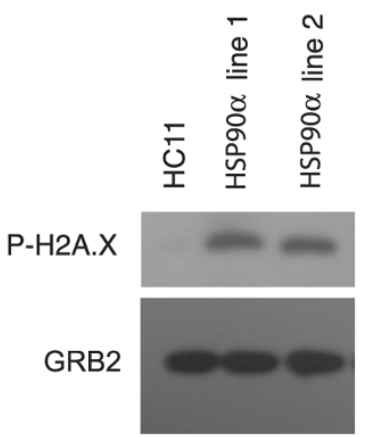

48 hours

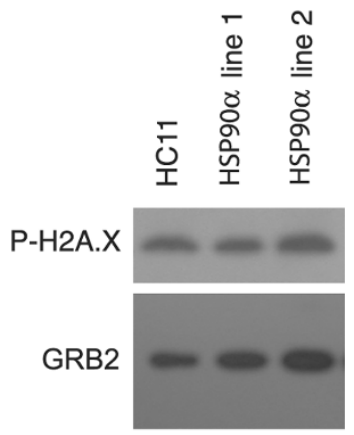

(c)

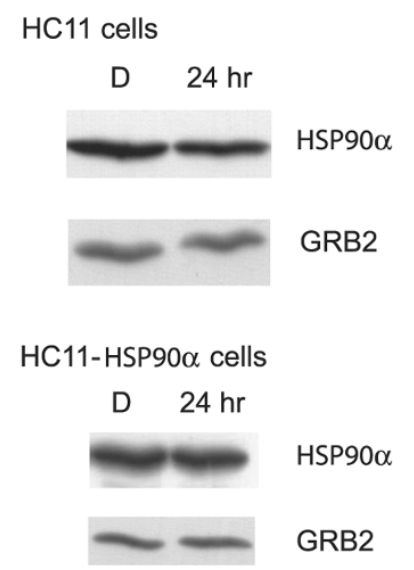

(d)

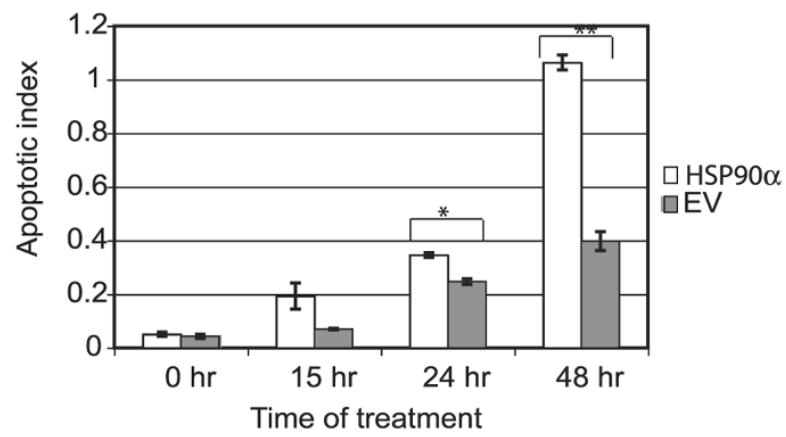

Constitutive HSP90A expression sensitizes cells to apoptosis. (a) Protein extracts were prepared from control parental HC11 or heat shock protein 90 alpha (HSP90 $\alpha$ )-HC11 (line 2) cells that were cultured as undifferentiated (U), competent (C) or differentiated (D) cells. (b, c) Differentiated parental HC11 and two different pools of HC11-HSP90 $\alpha$ cells (lines 1 and/or 2) were induced to differentiate and then starved of lactogenic hormones and serum for the time indicated. Equal amounts of protein were resolved by SDS-PAGE (15\%). An antibody was used to detect phosphorylated-histone 2A.X, and an antibody against GRB2 was used as a loading control. (d) Differentiated control HC11 and HC11-HSP90 $\alpha$ cells (line 2) were starved or not apoptosis was assessed by the relative quantities of mono- and oligo-nucleosomes (apoptotic index). Each bar represents the average of three experiments with standard deviation. $t$-test, ${ }^{*} p=0.02$ at 24 hours, ${ }^{\star *} p=0.00004$ at 48 hours.

decreases slightly, but remains more constant in the cells constitutively expressing HSP9OA, HC11-HSP90 $\alpha$ cells (Figure $5 c)$. We can not be certain that the effect on survival we observed (shown in Figure $5 \mathrm{~b}$ ) is due to the differential protein levels between the differentiated and starved cells in the two cell lines, or to the overall two-fold elevated levels of HSP90 $\alpha$ in the HC11-HSP90 $\alpha$ line. The greater amounts of phosphohistone 2A.X at 24 hours of starvation indicate that constitutive expression of the gene encoding HSP9O $\alpha$ increases levels of the marker for DNA damage, phospho-histone 2A.X, and may sensitise the cells to apoptosis.

To confirm that the phosphorylation of histone 2A.X represented events that occur during apoptosis, we also qualitatively assayed the mono- and oligo-nucleosomes generated due to apoptotic DNA nuclease activation. As both HC11HSP90 $\alpha$ cell lines behaved similarly, we used only line two for further characterisation. The $\mathrm{HC} 11$ cell lines were treated as shown in Figure 5b, and equal amounts of the cytoplasmic extracts were assessed for the presence of mono- and oligonucleosomes. HC11-HSP90 $\alpha$ cells clearly had higher levels of nucleosomes than control cells HC11-EV (empty vector) after 24 and 48 hours of starvation, indicating greater levels of apoptosis (Figure $5 \mathrm{~d}$ ). These results support that although prolactin acts as a survival factor in the absence of prolactin or other survival factors, $\mathrm{HC} 11$ cells constitutively expressing HSP90 $\alpha$ are sensitised to starvation-induced apoptosis.

We used the HSP90 inhibitor 17-AAG to confirm our results. First, we confirmed that HSP90 $\alpha$ promotes survival in the presence of prolactin and serum. Differentiated HC11HSP90 $\alpha$ (Figure 6a) or HC11-EV cells (Figure 6b) were untreated or treated with $1 \mu \mathrm{g} / \mathrm{mL} 17-A A G$ either in differentiation medium (dexamethasone, insulin and prolactin plus 
serum) or starvation medium (no serum or hormones) for a total of 24 hours before measuring apoptosis. Consistent with the role of HSP90 $\alpha$ promoting survival, inhibition of HSP90 by 17-AAG induced apoptosis in differentiated HC11-HSP90 $\alpha$ (Figure 6a) and HC11-EV cells (Figure 6b) in the presence of survival factors such as prolactin and serum. HSP90 $\alpha$ also promotes survival in the control HC11-EV cell line in starvation medium, as demonstrated by the increase in apoptosis with the addition of the inhibitor 17-AAG (Figure 6b).

Second, we confirmed that constitutive expression of HSP90 $\alpha$ promotes apoptosis in starved cells. Consistent with the effect of constitutive HSP90 $\alpha$ expression on the sensitisation of HC11 cells, 17-AAG reduced the starvation-induced apoptosis (Figure 6a). Overall, starvation enhanced the general level of apoptosis in differentiated cells of both cell lines, although the effects of the HSP90 inhibitor were different. Together this confirms our initial observations and indicates that HSP90 $\alpha$ functions to promote survival in differentiated cells in the presence of survival factors, but that constitutive expression sensitises these immortal mammary epithelial HC11 cells to starvation-induced apoptosis.

\section{HSP90 $\alpha$ promotes survival in breast cancer cells}

Increased expression of HSP90 $\alpha$ has been reported in breast cancer, including SKBR3 cells [35], and cytotoxicity has also been reported for the use of HSP90 $\alpha$ inhibitors in breast cancer cells, including SKBR3 [68-70]. To test the role of HSP90 $\alpha$ in SKBR3 cells, we assessed oligo-nucleasome formation in the presence and absence of 17-AAG and in the presence or absence of serum. HSP90 $\alpha$ promotes survival, in the presence of serum, as indicated by the increase in apoptosis after treatment with 17-AAG (Figure 7). Interestingly, overall there was less apoptosis in the absence of serum and the amount of apoptosis was independent of 17-AAG. In general, cancer cells are known to be resistant to apoptotic stimuli, but the role of HSP90 $\alpha$ in the absence of serum seems to be minimal. HSP90 $\alpha$ promotes survival of SKBR3 cells in the presence of serum.

\section{Discussion}

We used a subtractive hybridisation approach to identify a number of prolactin-regulated target genes in the human breast cancer cell line SKBR3. By focusing on the HSP9OA gene in particular, we determined that the HSP90 $\alpha$ protein has the potential to regulate survival differently in normal (immortal) mammary epithelial cells depending on the context of the hormonal milieu and the constitutive expression of the gene encoding $\mathrm{HSP} 90 \alpha$. As HSP90 $\alpha$ is a central therapeutic target for breast cancer treatment, this also elevates the importance of prolactin and specifically identifies one mechanism for its contribution to breast cancer.

\section{Prolactin regulated genes in breast cancer cells}

We identified a number of genes in our screen of breast cancer SKBR3 cells whose expression either increased or decreased in response to prolactin. Some of the genes have been previously associated with cancer progression ( $\mathrm{T}$ complex protein-1 beta [71], tetratricopeptide repeat protein-4 [72]), cancer survival (Bax inhibitor 1 [73], mitofusion 2 $[74,75])$, heterogeneous nuclear riboprotein A1 [76]), drug resistance (T complex protein-1, HSP70 [77]), or cancer cell migration ( $\mathrm{Hs} 1$ binding protein $[78,79])$. Prolactin signalling has been implicated in each of these phenomena in breast cancer cells though its role in drug resistance has not yet been thoroughly examined.

\section{Prolactin-JAK2-STAT5-regulates HSP90A, a therapeutically important gene}

In this study, we also identified HSP9OA as a prolactininduced STAT5-activated target gene. HSP90 $\alpha$ is a molecular chaperone of a large number of proteins involved in critical signal transduction pathways. The role of HSP90 $\alpha$ downstream of prolactin helps explain the multiple effects of prolactin in normal cells and emphasises the significant contribution of prolactin-JAK2-STAT5 signal transduction to breast cancer.

HSP90 in cancer cells is present in an active form, in a multichaperone complex with high ATPase activity, in contrast to the HSP90 in normal cells, which is in an inactive, uncomplexed form. It is thought that these differences account for the high affinity of cancer-associated HSP9O $\alpha$ for the inhibitory ATP mimetic drugs such as 17-AAG [38]. Chemotherapeutic drugs, such as 17-AAG, inhibit HSP90 and usually result in the degradation of HSP9O client proteins [80]. There are multiple client proteins of $\mathrm{HSP} 90 \alpha$, including steroid hormone receptors such as oestrogen receptor, protein kinases, cell cycle proteins and transcription factors that are essential targets in cancerous cell growth, survival, immortalisation, angiogenesis and metastasis [81]. The prolactin-mediated induction of HSP90 $\alpha$ implicates prolactin in the acquisition or maintenance of each of those cancer-related traits.

\section{Prolactin is a survival factor in HC11 cells}

We also determined that prolactin, dexamethasone and insulin, each act as survival factors in differentiated mammary epithelial HC11 cells. Insulin $[66,82]$ and the glucocorticoid receptor have previously been identified as survival factors $[83,84]$. There is existing evidence showing a survival role for prolactin in breast cancer cells [59-63], and for STAT5 in normal mammary epithelial cells [64,65]. The survival function of prolactin is partially due to the prolactin-mediated activation of AKT/protein kinase $B[85,86]$. AKT/protein kinase $B$ is a survival factor and a regulator of mammary gland involution, as transgenic mice expressing constitutively active AKT/protein kinase $B$ in the mammary gland showed delayed involution and a delayed onset of apoptosis $[87,88]$. AKT/protein kinase $B$ is also a client protein of HSP90 $[89,90]$. 
Figure 6

(a)

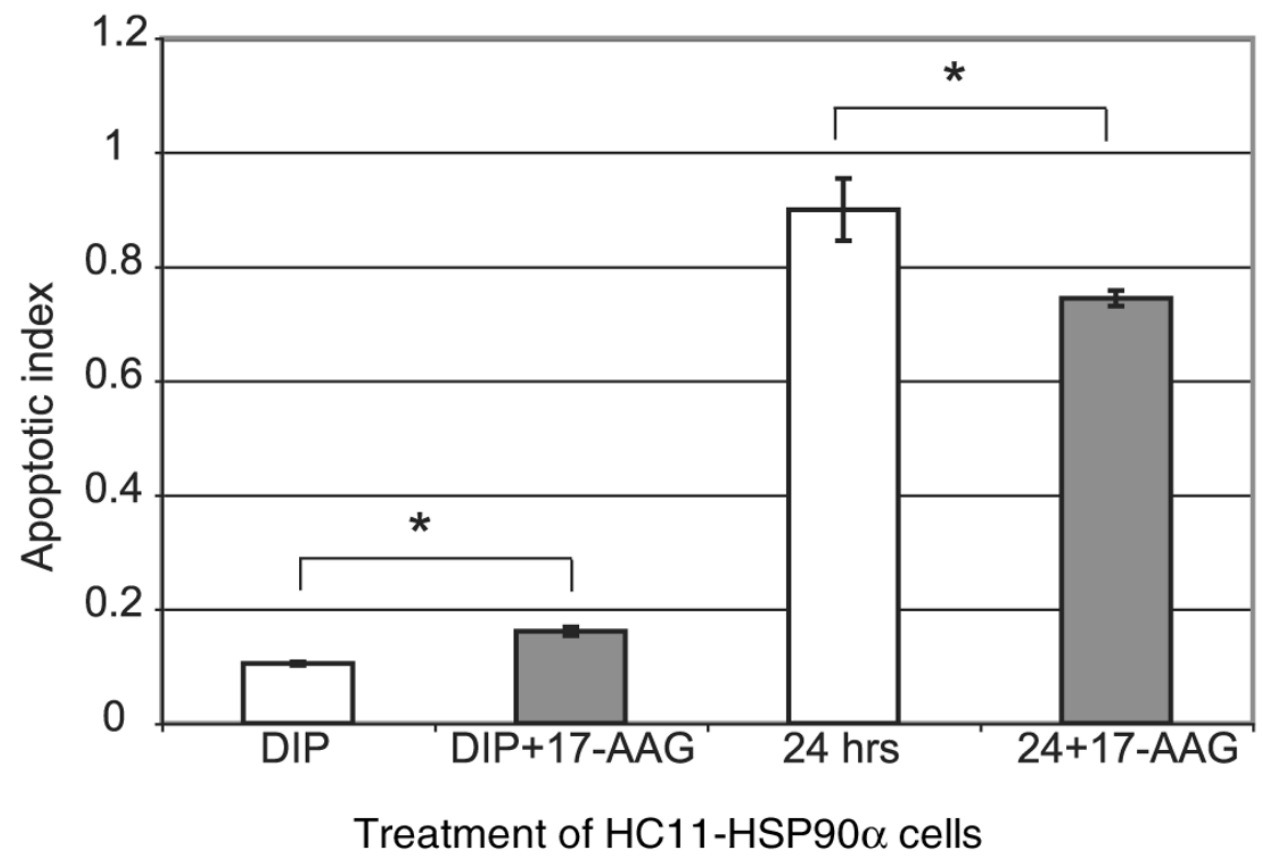

(b)

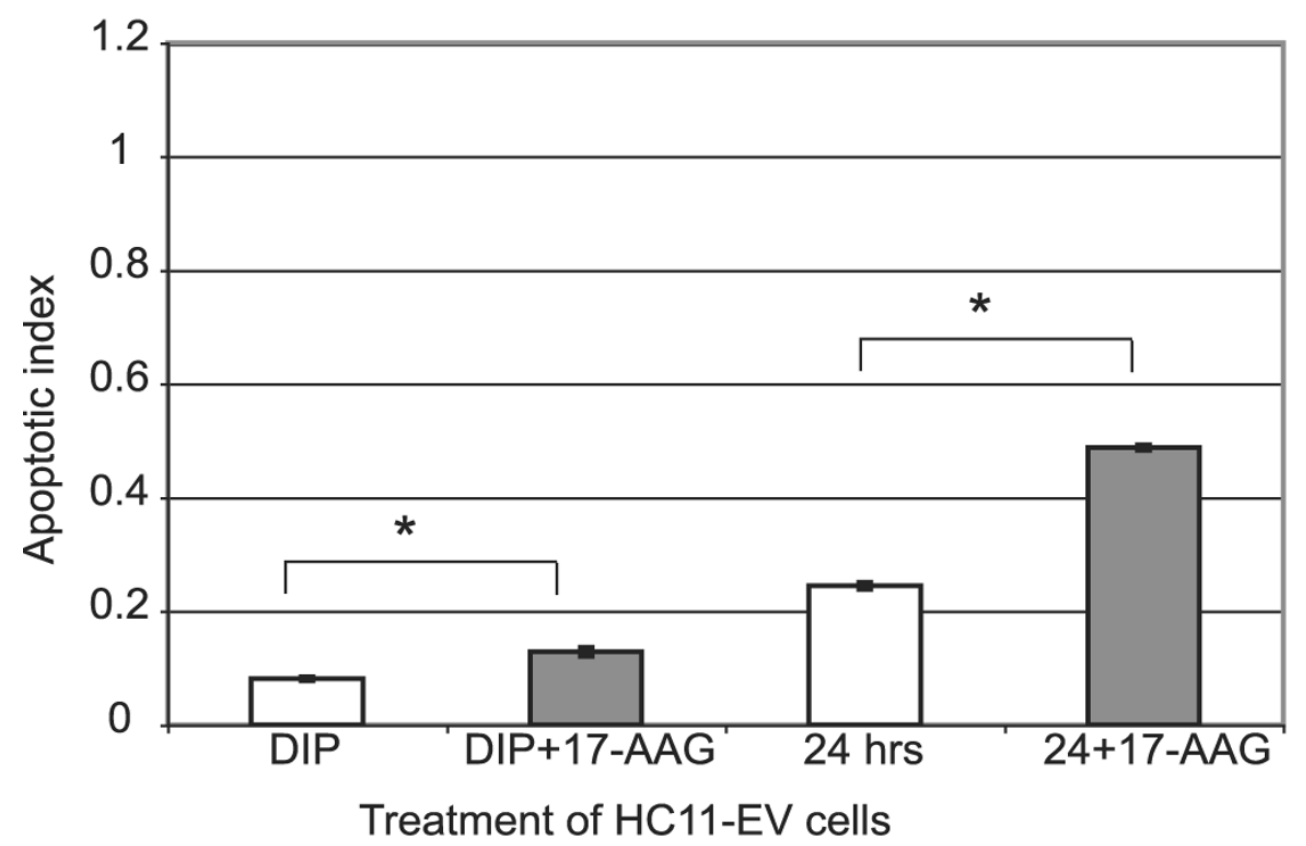

Inhibition of HSP90 $\alpha$ by 17-AAG defines roles for survival as well as apoptosis in HC11 cells. The presence of mono- and oligo-nucleosomes was measured as an indication of apoptosis (apoptotic index). (a) HC11-heat shock protein 90 alpha (HSP90 $\alpha$ ) cells or (b) $\mathrm{HC} 11$-EV cells were differentiated and left untreated or treated with $1 \mu \mathrm{M}$ of 17-allylamino-17-demethoxygeldanamycin (17-AAG) in either differentiation medium (prolactin, dexamethasone and insulin (DIP)) or starvation medium for 24 hours. Comparison of untreated to 17-AAG-treated HC11-HSP90 $\alpha$ (t-test ${ }^{\star} \mathrm{p}=$ 0.003) or HC11-EV (t-test ${ }^{*} \mathrm{p}=0.006$ ) cells after differentiation. Comparison of untreated to 17-AAG-treated HC11-HSP90 $\alpha$ (t-test $\left.{ }^{*} \mathrm{p}=0.04\right)$ or HC11-EV (t-test ${ }^{*} p=0.001$ ) cells in the absence of serum and hormones. Each bar represents the average of three experiments with standard deviation. Each cell line was tested independently and so the absolute levels of nucleosomes can be compared only within each panel. 


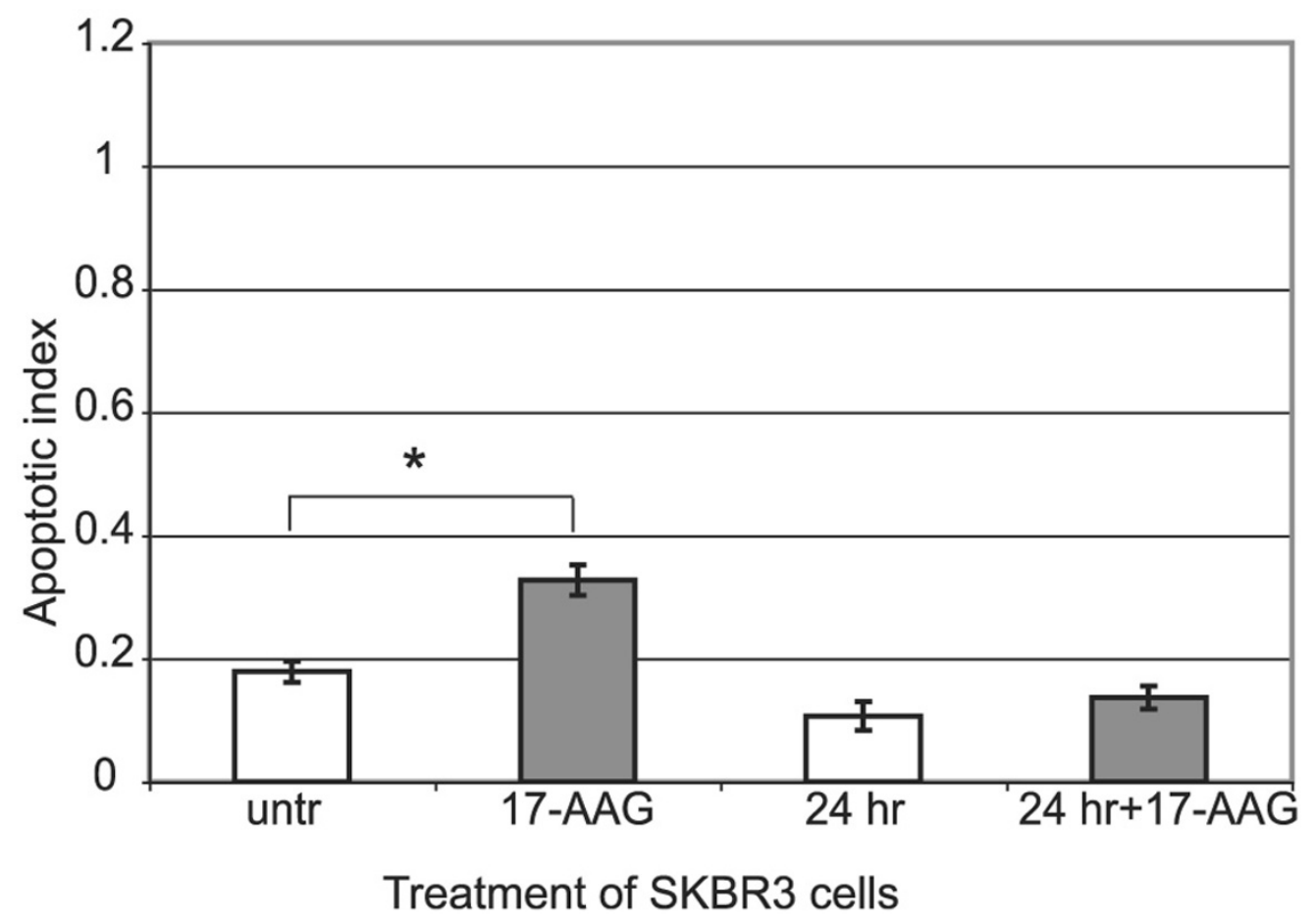

HSP90 $\alpha$ promotes survival only in the presence of serum in SKBR3 breast cancer cells. Apoptosis was assessed by measuring the presence of mono- and oligo-nucleosomes as an indication of apoptosis (apoptotic index). Addition of $500 \mathrm{nM} 17$-allylamino-17-demethoxygeldanamycin (17$A A G)$ to SKBR3 cells increases apoptosis ( $t$-test $\left.{ }^{*} p=0.01\right)$. Starvation alone reduces the overall level of apoptosis observed in SKBR3 cells with serum (untr) (t-test $p=0.004$ ). Each bar represents the average of three experiments with standard deviation. HSAP90 $\alpha=$ heat shock protein 90 alpha.

\section{HSP90 $\alpha$ promotes survival depending on the cellular context}

The prolactin-JAK2-STAT5 target gene, HSP90 $\alpha$, can contribute to survival in the presence of prolactin, but sensitises untransformed mammary epithelial $\mathrm{HC} 11$ cells to starvationinduced apoptosis when constitutively expressed. We confirmed these results with the use of 17-AAG.

There is evidence for the pro-apoptotic function of HSP9O $\alpha$ in other cell types [91-93]. We can also hypothesise that the proapoptotic function is due to the action of one of the client proteins either stabilised under these conditions, such as mutant p53, or disengagement from one of its client proteins such as AKT/protein kinase B. Although it is known that HSP90 stabilises mutant p53 forms [94], many of these mutant forms contribute to cellular immortalisation and transformation. The mutant forms of p53 in $\mathrm{HC} 11$ cells are thought to contribute to their immortalisation [95], but it is not known if, under certain conditions, mutant p53 could contribute to the sensitisation of cells to starvation-induced apoptosis as does wild-type p53 [96]. The fact that HSP90 can stabilise mutant p53 forms that can contribute to immortalisation and transformation emphasises a contribution of prolactin to these functions, as one of its upstream inducers.
We propose that the switch from survival to apoptosis in untransformed cells involves the loss of survival factors and the availability of HSP $90 \alpha$. In contrast, the switch is absent in SKBR3 breast cancer cells, which do not respond to 17-AAG during serum starvation. HSP90 is important for proliferation and survival, as SKBR3 cells have been shown to respond to $17-A A G$ by a reduction in proliferation $[68,70]$ and an increase in apoptosis $[68,69]$. This latter observation is consistent with our results in this report. Possible mechanisms involved in loss of HSP90-mediated survival after 17-AAG treatment include the loss of AKT/protein kinase B [97] or ERBB2 [69,98,99].

Together with our results, this indicates that in addition to a role in survival, $\mathrm{HSP} 90 \alpha$ also has a pro-apoptotic role that may be cell-type specific, specific to the hormone milieu in the environment or specific to the cellular state of transformation and complement of tumour-suppressor proteins. We hypothesise that $\mathrm{HSP} 90 \alpha$ together with prolactin-mediated events support survival in differentiated or cancerous cells, whereas HSP90 $\alpha$ alone may sensitise differentiated mammary cells to wild-type p53-independent apoptosis depending on the cellular context. 


\section{Conclusion}

The evidence for a contribution of prolactin and STAT5 to breast cancer cell survival, breast cancer progression and to chemotherapeutic response is strengthened by our observations that prolactin treatment of human breast cancer cells regulates a number of genes associated with cancer progression, including the therapeutically important target gene, HSP9OA. HSP9O $\alpha$ is important for malignant progression in breast cancer, but when elevated in untransformed mammary epithelial cells may participate in a switch between survival and apoptosis.

\section{Competing interests}

The authors declare that they have no competing interests.

\section{Authors' contributions}

$\mathrm{CP}$ provided data regarding HSP90 $\alpha$ protein levels. RL also participated in characterising HSP9O $\alpha$ levels and the response of cells to prolactin. CTP helped with luciferase assays. NB performed EMSA and northern blots. JS and PB provided bioinformatics support. CSS prepared and screened the library, contributing luciferase and apoptosis assays. EP, CSS and BG contributed to early project design. BG and CSS provided funding. CSS provided further project development and wrote the manuscript. All authors read and approved the final manuscript.

\section{Acknowledgements}

We would like to thank Margot Landerz for sequencing the large selection of candidate clones and Sabina Vogel for assistance in the initial screening of the library, as well as Drs E. Hickey and Lee Weber for the HSP9OA-luciferase reporter gene. The work of CSS, CP and RL was supported by grants from the Natural Sciences and Engineering Research Council of Canada, the Alberta Cancer Foundation and the Alberta Cancer Board.

\section{References}

1. Shemanko CS, Groner B: Transcription factors, cofactors and target genes mediating prolactin action. In Prolactin Edited by: Horseman ND. USA: Kluwer Academic Publishers; 2001:381-404.

2. Watson $\mathrm{CJ}$ : Involution: apoptosis and tissue remodelling that convert the mammary gland from milk factory to a quiescent organ. Breast Cancer Res 2006, 8:203.

3. Clarkson RW, Boland MP, Kritikou EA, Lee JM, Freeman TC, Tiffen $P G$, Watson CJ: The genes induced by signal transducer and activators of transcription (STAT)3 and STAT5 in mammary epithelial cells define the roles of these STATs in mammary development. Mol Endocrinol 2006, 20:675-685.

4. Tworoger SS, Eliassen AH, Rosner B, Sluss P, Hankinson SE: Plasma prolactin concentrations and risk of postmenopausal breast cancer. Cancer Res 2004, 64:6814-6819.

5. Nouhi Z, Chughtai N, Hartley S, Cocolakis E, Lebrun JJ, Ali S: Defining the role of prolactin as an invasion suppressor hormone in breast cancer cells. Cancer Res 2006, 66:1824-1832.

6. Clevenger CV, Furth PA, Hankinson SE, Schuler LA: The role of prolactin in mammary carcinoma. Endocr Rev 2003, 24:1-27.

7. Tworoger SS, Hankinson SE: Prolactin and breast cancer etiology: An epidemiologic perspective. J Mammary Gland Biol Neoplasia 2008, 13:41-53.

8. Arendt LM, Rose-Hellekant TA, Sandgren EP, Schuler LA: Prolactin potentiates transforming growth factor alpha induction of mammary neoplasia in transgenic mice. Am J Pathol 2006, 168:1365-1374.
9. Rose-Hellekant TA, Arendt LM, Schroeder MD, Gilchrist K, Sandgren EP, Schuler LA: Prolactin induces ERalpha-positive and ERalpha-negative mammary cancer in transgenic mice. Oncogene 2003, 22:4664-4674.

10. Wennbo H, Gebre-Medhin M, Gritli-Linde A, Ohlsson C, Isaksson $\mathrm{OG}$, Tornell J: Activation of the prolactin receptor but not the growth hormone receptor is important for induction of mammary tumors in transgenic mice. J Clin Invest 1997, 100:2744-2751.

11. Vomachka AJ, Pratt SL, Lockefeer JA, Horseman ND: Prolactin gene-disruption arrests mammary gland development and retards T-antigen-induced tumor growth. Oncogene 2000, 19:1077-1084.

12. Oakes SR, Robertson FG, Kench JG, Gardiner-Garden M, Wand MP, Green JE, Ormandy CJ: Loss of mammary epithelial prolactin receptor delays tumor formation by reducing cell proliferation in low-grade preinvasive lesions. Oncogene 2007, 26:543-553.

13. Tworoger SS, Eliassen $\mathrm{AH}$, Sluss $\mathrm{P}$, Hankinson SE: A prospective study of plasma prolactin concentrations and risk of premenopausal and postmenopausal breast cancer. J Clin Oncol 2007, 25:1482-1488

14. Rhodes DR, Yu J, Shanker K, Deshpande N, Varambally R, Ghosh D, Barrette T, Pandey A, Chinnaiyan AM: ONCOMINE: a cancer microarray database and integrated data-mining platform. Neoplasia 2004, 6:1-6.

15. Bertucci $F$, Nasser V, Granjeaud S, Eisinger F, Adelaide J, Tagett R, Loriod B, Giaconia A, Benziane A, Devilard E, Jacquemier J, Viens P, Nguyen C, Birnbaum D, Houlgatte R: Gene expression profiles of poor-prognosis primary breast cancer correlate with survival. Hum Mol Genet 2002, 11:863-872.

16. Turkson J: STAT proteins as novel targets for cancer drug discovery. Expert Opin Ther Targets 2004, 8:409-422.

17. Wagner $\mathrm{KU}$, Rui $\mathrm{H}$ : Jak2/Stat5 signaling in mammogenesis breast cancer initiation and progression. J Mammary Gland Biol Neoplasia 2008, 13:93-103.

18. Brisken C, Ayyannan A, Nguyen C, Heineman A, Reinhardt F, Tan J, Dey SK, Dotto GP, Weinberg RA, Jan T: IGF-2 is a mediator of prolactin-induced morphogenesis in the breast. Dev Cell 2002, 3:877-887.

19. Gass S, Harris J, Ormandy C, Brisken C: Using gene expression arrays to elucidate transcriptional profiles underlying prolactin function. J Mammary Gland Biol Neoplasia 2003, 8:269-285.

20. Harris J, Stanford PM, Sutherland K, Oakes SR, Naylor MJ, Robertson FG, Blazek KD, Kazlauskas M, Hilton HN, Wittlin S, Alexander WS, Lindeman GJ, Visvader JE, Ormandy CJ: Socs2 and elf5 mediate prolactin-induced mammary gland development. $\mathrm{Mol}$ Endocrinol 2006, 20:1177-1187.

21. Hou Z, Bailey JP, Vomachka AJ, Matsuda M, Lockefeer JA, Horseman ND: Glycosylation-dependent cell adhesion molecule 1 (GlyCAM 1) is induced by prolactin and suppressed by progesterone in mammary epithelium. Endocrinology 2000, 141:4278-4283

22. Naylor MJ, Ginsburg E, lismaa TP, Vonderhaar BK, Wynick D, Ormandy CJ: The neuropeptide galanin augments lobuloalveolar development. J Biol Chem 2003, 278:29145-29152.

23. Naylor MJ, Oakes SR, Gardiner-Garden M, Harris J, Blazek K, Ho TW, Li FC, Wynick D, Walker AM, Ormandy CJ: Transcriptional changes underlying the secretory activation phase of mammary gland development. Mol Endocrinol 2005, 19:1868-1883.

24. Ormandy CJ, Naylor M, Harris J, Robertson F, Horseman ND, Lindeman GJ, Visvader J, Kelly PA: Investigation of the transcriptional changes underlying functional defects in the mammary glands of prolactin receptor knockout mice. Recent Prog Horm Res 2003, 58:297-323.

25. Neckers L: Heat shock protein 90: the cancer chaperone. J Biosci 2007, 32:517-530.

26. Workman P, Burrows F, Neckers L, Rosen N: Drugging the cancer chaperone HSP90: combinatorial therapeutic exploitation of oncogene addiction and tumor stress. Ann NY Acad Sci 2007, 1113:202-216.

27. Beliakoff J, Whitesell L: Hsp90: an emerging target for breast cancer therapy. Anticancer Drugs 2004, 15:651-662.

28. Cullinan SB, Whitesell L: Heat shock protein 90: a unique chemotherapeutic target. Semin Oncol 2006, 33:457-465. 
29. Workman P, Maloney A: HSP90 as a new therapeutic target for cancer therapy: the story unfolds. Expert Opin Biol Ther 2002, 2:3-24.

30. Queitsch C, Sangster TA, Lindquist S: Hsp90 as a capacitor of phenotypic variation. Nature 2002, 417:618-624.

31. Rutherford SL, Lindquist S: Hsp90 as a capacitor for morphological evolution. Nature 1998, 396:336-342.

32. Eustace BK, Sakurai T, Stewart JK, Yimlamai D, Unger C, Zehetmeier C, Lain B, Torella C, Henning SW, Beste G, Scroggins BT, Neckers L, llag LL, Jay DG: Functional proteomic screens reveal an essential extracellular role for hsp90 alpha in cancer cell invasiveness. Nat Cell Biol 2004, 6:507-514.

33. Teng SC, Chen YY, Su YN, Chou PC, Chiang YC, Tseng SF, Wu $\mathrm{KJ}$ : Direct activation of HSP90A transcription by c-Myc contributes to c-Myc-induced transformation. J Biol Chem 2004, 279:14649-14655.

34. Csermely P, Schnaider T, Soti C, Prohaszka Z, Nardai G: The 90kDa molecular chaperone family: structure, function, and clinical applications. A comprehensive review. Pharmacol Ther 1998, 79:129-168.

35. Pick E, Kluger Y, Giltnane JM, Moeder C, Camp RL, Rimm DL, Kluger HM: High HSP90 expression is associated with decreased survival in breast cancer. Cancer Res 2007, 67:2932-2937.

36. Yano M, Naito Z, Tanaka S, Asano G: Expression and roles of heat shock proteins in human breast cancer. Jpn J Cancer Res 1996, 87:908-915

37. Yano $M$, Naito $Z$, Yokoyama $M$, Shiraki $Y$, Ishiwata $T$, Inokuchi $M$, Asano G: Expression of hsp90 and cyclin D1 in human breast cancer. Cancer Lett 1999, 137:45-51.

38. Kamal A, Thao L, Sensintaffar J, Zhang L, Boehm MF, Fritz LC, Burrows FJ: A high-affinity conformation of $\mathrm{Hsp} 90$ confers tumour selectivity on Hsp90 inhibitors. Nature 2003, 425:407-410.

39. Powers MV, Workman P: Targeting of multiple signalling pathways by heat shock protein 90 molecular chaperone inhibitors. Endocr Relat Cancer 2006, 13(Suppl 1):S125-135.

40. Modi S, Stopeck AT, Gordon MS, Mendelson D, Solit DB, Bagatell R, Ma W, Wheler J, Rosen N, Norton L, Cropp GF, Johnson RG, Hannah AL, Hudis CA: Combination of trastuzumab and tanespimycin (17-AAG, KOS-953) is safe and active in trastuzumab-refractory HER-2 overexpressing breast cancer: a phase I dose-escalation study. J Clin Oncol 2007, 25:5410-5417.

41. Sharp S, Workman P: Inhibitors of the HSP90 molecular chaperone: current status. Adv Cancer Res 2006, 95:323-348.

42. Tuna M, Chavez-Reyes A, Tari AM: HER2/neu increases the expression of Wilms' Tumor 1 (WT1) protein to stimulate Sphase proliferation and inhibit apoptosis in breast cancer cells. Oncogene 2005, 24:1648-1652.

43. Liu X, Robinson GW, Gouilleux F, Groner B, Hennighausen L: Cloning and expression of Stat 5 and an additional homologue (Stat5b) involved in prolactin signal transduction in mouse mammary tissue. Proc Natl Acad Sci USA 1995, 92:8831-8835.

44. Wakao H, Gouilleux F, Groner B: Mammary gland factor (MGF) is a novel member of the cytokine regulated transcription factor gene family and confers the prolactin response. Embo $J$ 1994, 13:2182-2191.

45. Ball RK, Friis RR, Schoenenberger CA, Doppler W, Groner B: Prolactin regulation of beta-casein gene expression and of a cytosolic $120-k d$ protein in a cloned mouse mammary epithelial cell line. Embo J 1988, 7:2089-2095.

46. Uchida $\mathrm{K}$, Yoshimura A, Inazawa J, Yanagisawa $\mathrm{K}$, Osada $\mathrm{H}$, Masuda A, Saito T, Takahashi T, Miyajima A: Molecular cloning of $\mathrm{CISH}$, chromosome assignment to $3 \mathrm{p} 21.3$, and analysis of expression in fetal and adult tissues. Cytogenet Cell Genet 1997, 78:209-212.

47. Wakao H, Schmitt-Ney M, Groner B: Mammary gland-specific nuclear factor is present in lactating rodent and bovine mammary tissue and composed of a single polypeptide of $89 \mathrm{kDa}$. $\mathrm{J}$ Biol Chem 1992, 267:16365-16370.

48. Gouilleux F, Wakao H, Mundt M, Groner B: Prolactin induces phosphorylation of Tyr694 of Stat5 (MGF), a prerequisite for DNA binding and induction of transcription. Embo J 1994, 13:4361-4369.

49. Shaw-Bruha CM, Pirrucello SJ, Shull JD: Expression of the prolactin gene in normal and neoplastic human breast tissues and human mammary cell lines: promoter usage and alternative mRNA splicing. Breast Cancer Res Treat 1997, 44:243-253.

50. Yoshimura A, Ohkubo T, Kiguchi T, Jenkins NA, Gilbert DJ, Copeland NG, Hara T, Miyajima A: A novel cytokine-inducible gene $\mathrm{CIS}$ encodes an $\mathrm{SH} 2$-containing protein that binds to tyrosinephosphorylated interleukin 3 and erythropoietin receptors. Embo J 1995, 14:2816-2826.

51. Matsumoto A, Masuhara M, Mitsui K, Yokouchi M, Ohtsubo M, Misawa $\mathrm{H}$, Miyajima A, Yoshimura A: CIS, a cytokine inducible SH2 protein, is a target of the JAK-STAT5 pathway and modulates STAT5 activation. Blood 1997, 89:3148-3154.

52. Verdier F, Rabionet R, Gouilleux F, Beisenherz-Huss C, Varlet $P$ Muller O, Mayeux P, Lacombe C, Gisselbrecht S, Chretien S: A sequence of the CIS gene promoter interacts preferentially with two associated STAT5A dimers: a distinct biochemical difference between STAT5A and STAT5B. Mol Cell Biol 1998, 18:5852-5860.

53. Bole-Feysot C, Perret E, Roustan P, Bouchard B, Kelly PA: Analysis of prolactin-modulated gene expression profiles during the $\mathrm{Nb2}$ cell cycle using differential screening techniques. Genome Biol 2000, 1:RESEARCH0008.

54. Djiane J, Houdebine LM, Kelly PA: Correlation between prolactin-receptor interaction, down-regulation of receptors, and stimulation of casein and deoxyribonucleic acid biosynthesis in rabbit mammary gland explants. Endocrinology 1982, 110:791-795.

55. Desrivières $\mathrm{S}$, Prinz T, Castro-Palomino Laria N, Meyer M, Boehm G, Bauer U, Schäfer J, Neumann T, Groner B, Shemanko CS: Comparative proteomic analysis of proliferating and functionally differentiated mammary epithelial cells. Molecular and Cellular Proteomics 2003, 2:1039-1054.

56. Decker T, Kovarik P, Meinke A: GAS elements: a few nucleotides with a major impact on cytokine-induced gene expression. $J$ Interferon Cytokine Res 1997, 17:121-134.

57. Calo V, Migliavacca M, Bazan V, Macaluso M, Buscemi M, Gebbia N, Russo A: STAT proteins: from normal control of cellular events to tumorigenesis. J Cell Physio/ 2003, 197:157-168.

58. Weaver AM, Silva CM: Modulation of signal transducer and activator of transcription $5 \mathrm{~b}$ activity in breast cancer cells by mutation of tyrosines within the transactivation domain. $\mathrm{Mol}$ Endocrinol 2006, 20:2392-2405.

59. Abdelmagid SA, Too CK: Prolactin and Estrogen Upregulate Carboxypeptidase-D to Promote Nitric Oxide Production and Survival of MCF-7 Breast Cancer Cells. Endocrinology 2008.

60. Chakravarti $P$, Henry MK, Quelle FW: Prolactin and heregulin override DNA damage-induced growth arrest and promote phosphatidylinositol-3 kinase-dependent proliferation in breast cancer cells. Int J Oncol 2005, 26:509-514.

61. Chen WY, Ramamoorthy P, Chen N, Sticca R, Wagner TE: A human prolactin antagonist, hPRL-G129R, inhibits breast cancer cell proliferation through induction of apoptosis. Clin Cancer Res 1999, 5:3583-3593.

62. Ginsburg E, Vonderhaar BK: Prolactin synthesis and secretion by human breast cancer cells. Cancer Res 1995, 55:2591-2595.

63. Perks CM, Keith AJ, Goodhew KL, Savage PB, Winters ZE, Holly $\mathrm{JM}$ : Prolactin acts as a potent survival factor for human breast cancer cell lines. Br J Cancer 2004, 91:305-311.

64. Cui Y, Riedlinger G, Miyoshi K, Tang W, Li C, Deng CX, Robinson GW, Hennighausen L: Inactivation of Stat5 in mouse mammary epithelium during pregnancy reveals distinct functions in cell proliferation, survival, and differentiation. Mol Cell Biol 2004, 24:8037-8047.

65. lavnilovitch E, Eilon T, Groner B, Barash I: Expression of a carboxy terminally truncated Stat 5 with no transactivation domain in the mammary glands of transgenic mice inhibits cell proliferation during pregnancy, delays onset of milk secretion, and induces apoptosis upon involution. Mol Reprod Dev 2006, 73:841-849.

66. Merlo GR, Basolo F, Fiore L, Duboc L, Hynes NE: p53-dependent and p53-independent activation of apoptosis in mammary epithelial cells reveals a survival function of EGF and insulin. $J$ Cell Biol 1995, 128:1185-1196.

67. Rogakou EP, Nieves-Neira W, Boon C, Pommier Y, Bonner WM: Initiation of DNA fragmentation during apoptosis induces phosphorylation of $\mathrm{H} 2 \mathrm{AX}$ histone at serine 139. J Biol Chem 2000, 275:9390-9395. 
68. Munster PN, Marchion DC, Basso AD, Rosen N: Degradation of HER2 by ansamycins induces growth arrest and apoptosis in cells with HER2 overexpression via a HER3, phosphatidylinositol 3'-kinase-AKT-dependent pathway. Cancer Res 2002, 62:3132-3137.

69. Solit DB, Basso AD, Olshen AB, Scher HI, Rosen N: Inhibition of heat shock protein $\mathbf{9 0}$ function down-regulates Akt kinase and sensitizes tumors to Taxol. Cancer Res 2003, 63:2139-2144.

70. Zsebik B, Citri A, Isola J, Yarden Y, Szollosi J, Vereb G: Hsp90 inhibitor 17-AAG reduces ErbB2 levels and inhibits proliferation of the trastuzumab resistant breast tumor cell line JIMT-1. Immunol Lett 2006, 104:146-155.

71. Coghlin C, Carpenter B, Dundas SR, Lawrie LC, Telfer C, Murray Gl: Characterization and over-expression of chaperonin tcomplex proteins in colorectal cancer. J Pathol 2006, 210:351-357.

72. Poetsch M, Dittberner T, Cowell JK, Woenckhaus C: TTC4, a novel candidate tumor suppressor gene at $1 \mathrm{p} 31$ is often mutated in malignant melanoma of the skin. Oncogene 2000, 19:5817-5820.

73. Grzmil M, Thelen P, Hemmerlein B, Schweyer S, Voigt S, Mury D, Burfeind $\mathrm{P}$ : Bax inhibitor-1 is overexpressed in prostate cancer and its specific down-regulation by RNA interference leads to cell death in human prostate carcinoma cells. Am J Pathol 2003, 163:543-552.

74. Brooks C, Wei Q, Feng L, Dong G, Tao Y, Mei L, Xie ZJ, Dong Z: Bak regulates mitochondrial morphology and pathology during apoptosis by interacting with mitofusins. Proc Natl Acad Sci USA 2007, 104:11649-11654.

75. Neuspiel M, Zunino R, Gangaraju S, Rippstein P, McBride H: Activated mitofusin 2 signals mitochondrial fusion, interferes with Bax activation, and reduces susceptibility to radical induced depolarization. J Biol Chem 2005, 280:25060-25070.

76. Patry C, Bouchard L, Labrecque P, Gendron D, Lemieux B, Toutant J, Lapointe E, Wellinger R, Chabot B: Small interfering RNAmediated reduction in heterogeneous nuclear ribonucleoparticule A1/A2 proteins induces apoptosis in human cancer cells but not in normal mortal cell lines. Cancer Res 2003, 63:7679-7688.

77. Verrills NM, Liem NL, Liaw TY, Hood BD, Lock RB, Kavallaris M: Proteomic analysis reveals a novel role for the actin cytoskeleton in vincristine resistant childhood leukemia - an in vivo study. Proteomics 2006, 6:1681-1694.

78. Radhika V, Onesime D, Ha JH, Dhanasekaran N: Galpha13 stimulates cell migration through cortactin-interacting protein Hax-1. J Biol Chem 2004, 279:49406-49413.

79. Ramsay AG, Keppler MD, Jazayeri M, Thomas GJ, Parsons M, Violette S, Weinreb P, Hart IR, Marshall JF: HS1-associated protein $X-1$ regulates carcinoma cell migration and invasion via clathrin-mediated endocytosis of integrin alphavbeta6. Cancer Res 2007, 67:5275-5284

80. Whitesell L, Lindquist SL: HSP90 and the chaperoning of cancer. Nat Rev Cancer 2005, 5:761-772.

81. Workman P: Combinatorial attack on multistep oncogenesis by inhibiting the Hsp90 molecular chaperone. Cancer Lett 2004, 206:149-157.

82. Merlo GR, Graus-Porta D, Cella N, Marte BM, Taverna D, Hynes NE: Growth, differentiation and survival of HC11 mammary epithelial cells: diverse effects of receptor tyrosine kinaseactivating peptide growth factors. Eur J Cell Biol 1996, 70:97-105.

83. Wu W, Zou M, Brickley DR, Pew T, Conzen SD: Glucocorticoid receptor activation signals through forkhead transcription factor $3 a$ in breast cancer cells. Mol Endocrinol 2006, 20:2304-2314

84. Schorr K, Furth PA: Induction of bcl-xL expression in mammary epithelial cells is glucocorticoid-dependent but not signal transducer and activator of transcription 5-dependent. Cancer Res 2000, 60:5950-5953.

85. al-Sakkaf KA, Dobson PR, Brown BL: Prolactin induced tyrosine phosphorylation of p59fyn may mediate phosphatidylinositol 3-kinase activation in Nb2 cells. J Mol Endocrinol 1997, 19:347-350.

86. Bailey JP, Nieport KM, Herbst MP, Srivastava S, Serra RA, Horseman ND: Prolactin and transforming growth factor-beta signaling exert opposing effects on mammary gland morphogenesis, involution, and the Akt-forkhead pathway. Mol Endocrinol 2004, 18:1171-1184.

87. Hutchinson J, Jin J, Cardiff RD, Woodgett JR, Muller WJ: Activation of Akt (protein kinase B) in mammary epithelium provides a critical cell survival signal required for tumor progression. Mol Cell Biol 2001, 21:2203-2212.

88. Schwertfeger KL, Richert MM, Anderson SM: Mammary gland involution is delayed by activated Akt in transgenic mice. Mol Endocrinol 2001, 15:867-881.

89. Basso AD, Solit DB, Chiosis G, Giri B, Tsichlis P, Rosen N: Akt forms an intracellular complex with heat shock protein 90 (Hsp90) and Cdc37 and is destabilized by inhibitors of Hsp90 function. J Biol Chem 2002, 277:39858-39866.

90. Sato S, Fujita N, Tsuruo T: Modulation of Akt kinase activity by binding to Hsp90. Proc Natl Acad Sci USA 2000 97:10832-10837.

91. Galea-Lauri J, Richardson AJ, Latchman DS, Katz DR: Increased heat shock protein 90 (hsp90) expression leads to increased apoptosis in the monoblastoid cell line U937 following induction with TNF-alpha and cycloheximide: a possible role in immunopathology. J Immunol 1996, 157:4109-4118.

92. Sapozhnikov AM, Ponomarev ED, Tarasenko TN, Telford WG: Spontaneous apoptosis and expression of cell surface heatshock proteins in cultured EL-4 lymphoma cells. Cell Prolif 1999, 32:363-378.

93. Wu YP, Kita K, Suzuki N: Involvement of human heat shock protein 90 alpha in nicotine-induced apoptosis. Int J Cancer 2002 100:37-42.

94. Whitesell L, Sutphin PD, Pulcini EJ, Martinez JD, Cook PH: The physical association of multiple molecular chaperone proteins with mutant p53 is altered by geldanamycin, an hsp90-binding agent. Mol Cell Biol 1998, 18:1517-1524.

95. Merlo GR, Venesio T, Taverna D, Marte BM, Callahan R, Hynes NE: Growth suppression of normal mammary epithelial cells by wild-type p53. Oncogene 1994, 9:443-453.

96. Blagosklonny MV, Wu GS, Somasundaram K, E S, W D: Wild-type p53 is not sufficient for serum starvation-induced apoptosis in cancer cells but accelerates apoptosis in sensitive cells. International Journal of Oncology 1997, 11:1165-1170.

97. Basso AD, Solit DB, Munster PN, Rosen N: Ansamycin antibiotics inhibit Akt activation and cyclin D expression in breast cancer cells that overexpress HER2. Oncogene 2002 21:1159-1166.

98. Wang K, Ma Q, Ren Y, He J, Zhang Y, Zhang Y, Chen W: Geldanamycin destabilizes HER2 tyrosine kinase and suppresses Wnt/beta-catenin signaling in HER2 overexpressing human breast cancer cells. Oncol Rep 2007, 17:89-96.

99. Xu W, Yuan X, Jung YJ, Yang Y, Basso A, Rosen N, Chung EJ, Trepel J, Neckers L: The heat shock protein 90 inhibitor geldanamycin and the ErbB inhibitor ZD1839 promote rapid PP1 phosphatase-dependent inactivation of AKT in ErbB2 overexpressing breast cancer cells. Cancer Res 2003, 63:7777-7784. 